\title{
In situ measurements of aerosol optical properties and number size distributions in a coastal region of Norway during the summer of 2008
}

\author{
S. Mogo ${ }^{1,2,3}$, V. E. Cachorro ${ }^{1}$, J. F. Lopez ${ }^{1}$, E. Montilla ${ }^{1, *}$, B. Torres ${ }^{1}$, E. Rodríguez ${ }^{4}$, Y. Bennouna ${ }^{1}$, and \\ A. M. de Frutos ${ }^{1}$ \\ ${ }^{1}$ Universidad de Valladolid, Grupo de Óptica Atmosférica, Spain \\ ${ }^{2}$ Universidade da Beira Interior, Faculdade de Ciências, Covilhã, Portugal \\ ${ }^{3}$ Instituto Dom Luis, Portugal \\ ${ }^{4}$ Finnish Meteorological Institute, Climate Change Unit, Helsinki, Finland \\ *now at: Universidad de Concepción, Center for Optics and Photonics, Chile
}

Correspondence to: S. Mogo (sipmogo@gmail.com)

Received: 30 September 2011 - Published in Atmos. Chem. Phys. Discuss.: 13 December 2011

Revised: 4 June 2012 - Accepted: 11 June 2012 - Published: 6 July 2012

\begin{abstract}
In situ measurements of aerosol optical properties and particle size distributions were made in the summer of 2008 at the ALOMAR station facility $\left(69^{\circ} 16^{\prime} \mathrm{N}, 16^{\circ} 00^{\prime} \mathrm{E}\right)$, located in a rural site in the north of the island of Andøya (Vesterålen archipelago), approximately $300 \mathrm{~km}$ north of the Arctic Circle. The extended three-month campaign was part of the POLARCAT Project (Polar Study using Aircraft, Remote Sensing, Surface Measurements and Models, of Climate, Chemistry, Aerosols, and Transport) of the International Polar Year (IPY-2007-2008). Our goal was to characterize the aerosols of this sub-Arctic area, which are frequently transported to the Arctic region.

Data from 13 June to 26 August 2008 were available and the statistical data for all instruments were calculated based on the hourly averages. The overall data coverage was approximately $72 \%$. The hourly mean values of the light-scattering coefficient, $\sigma_{\mathrm{s}}$, and the light-absorption coefficient, $\sigma_{\mathrm{a}}$, at $550 \mathrm{~nm}$ were $5.41 \mathrm{Mm}^{-1}\left(\mathrm{StD}=3.55 \mathrm{Mm}^{-1}\right)$ and $0.40 \mathrm{Mm}^{-1}\left(\mathrm{StD}=0.27 \mathrm{Mm}^{-1}\right)$, respectively. The scattering/absorption Ångström exponents, $\alpha_{\mathrm{s}, \mathrm{a}}$, were used in a detailed analysis of the variations of the spectral shape of $\sigma_{\mathrm{s}, \mathrm{a}}$. While $\alpha_{\mathrm{s}}$ indicates the presence of two particle sizes corresponding to two types of aerosols, $\alpha_{\mathrm{a}}$ indicates only one type of absorbing aerosol particle. $\alpha_{\mathrm{a}}$ values greater than 1 were not observed. The single-scattering albedo, $\omega_{0}$, ranged from 0.62 to $0.99($ mean $=0.91, \mathrm{StD}=0.05)$,
\end{abstract}

and the relationships between this parameter and the absorption/scattering coefficients and the Ångström exponents are presented. Any absorption value may lead to the lowest values of $\omega_{0}$, whereas only the lowest scattering values were observed in the lowest range of $\omega_{0}$. For a given absorption value, lower $\omega_{0}$ were observed for smaller $\alpha_{\mathrm{s}}$. The submicrometer, micrometer and total concentrations of the particles presented hourly mean values of $1277 \mathrm{~cm}^{-3}$ $\left(\mathrm{StD}=1563 \mathrm{~cm}^{-3}\right), 1 \mathrm{~cm}^{-3}\left(\mathrm{StD}=1 \mathrm{~cm}^{-3}\right)$ and $2463 \mathrm{~cm}^{-3}$ $\left(\mathrm{StD}=4251 \mathrm{~cm}^{-3}\right)$, respectively, and the modal correlations were also investigated. The optical and microphysical parameters, as well as their relationship with each other, are reported. $\sigma_{\mathrm{s}}$ correlated strongly with the number concentration of accumulation mode particles and more strongly with the micrometer fraction of particles, but weak correlations were observed for the Aitken and nucleation modes. The origins and pathways of the air masses were examined, and based on sector classification, a relationship between the air mass origin, the optical parameters and the size distributions was established.

The low values of the optical and microphysical parameters indicate that the predominant regional aerosol is mostly clean and the shape of the size distribution is characterized by bimodal median size distributions. However, the relationships between the air mass origins and the parameters studied allow us to describe two characteristic situations: the one 
of the northern and western air masses, which were predominantly composed of marine aerosols and presented the lowest optical and microphysical values observed, indicating predominantly non-absorbent and coarser particles; and the one of the eastern and southern air masses, in which continental aerosols were predominant and exhibited higher values for all parameters, indicating the presence of smaller absorbent particles. The north-northeastern air masses presented the strongest Aitken mode, indicating more recently formed particles, and the southeastern air masses presented the strongest accumulation mode (however, the southeastern air masses were the least common, accounting for only $3 \%$ of occurrences).

\section{Introduction}

The net effect of aerosols on global climate change is uncertain, since the particles involved can cause cooling or warming, depending on their optical properties. The reduction in the intensity of a direct solar beam during its propagation through the atmosphere is determined by both absorption and scattering processes. The aerosol single-scattering albedo, $\omega_{0}$, is defined as the ratio between the aerosol light scattering and the extinction, $\omega_{0}=\sigma_{\mathrm{s}} /\left(\sigma_{\mathrm{s}}+\sigma_{\mathrm{a}}\right)$, where $\sigma_{\mathrm{s}}$ and $\sigma_{\mathrm{a}}$ are the aerosol scattering and absorption coefficients, respectively. $\omega_{0}$ is one of the most relevant optical properties of aerosols, because the direct radiative effect of aerosols is very sensitive to this parameter. The optical properties of aerosol particles suspended in the atmosphere are determined by their chemical composition, size, shape, concentration and state of mixing and generally exhibit large spatial and temporal variability (Kokhanovsky, 2008).

Sulfate and nitrate aerosols from anthropogenic sources are thought to be the primary particles responsible for net cooling. These particles scatter solar radiation and are effective as cloud condensation nuclei that affect cloud longevity and the hydrological cycle and result in a negative radiative forcing that leads to a cooling of the Earth's surface. To some extent, sulfate and nitrate aerosols are thought to counteract global warming caused by greenhouse gases such as carbon dioxide (Boucher and Haywood, 2001). Sea-salt and nonsea-salt sulfate have been reported as dominating the light scattering effect in the Arctic (Quinn et al., 2002). Previous studies have also reported on the occurrence of large concentrations of biogenic scattering aerosols in the Arctic region, derived from the oxidation of atmospheric dimethylsulfide, which results from oceanic phytoplankton processes (Quinn et al., 2002). It has also been suggested that the organic species play important roles in aerosol light scattering (Quinn et al., 2002) and are an important component of Arctic aerosols in general (Quinn et al., 2002; Ricard et al., 2002a,b; Leck and Bigg, 2005).
On the other hand, light-absorbing particles, mainly formed by black carbon produced by the incomplete combustion of carbonaceous fuels, are effective absorbers of solar radiation and therefore contribute to warming the atmosphere. Absorption of solar radiation by aerosols causes heating of the lower troposphere, which may lead to altered vertical stability and has implications for the hydrological cycle (Ramanathan et al., 2001). In addition, the deposition of light-absorbing particles onto snow and ice reduces the surface albedo, which, in turn, affects the snow pack and the Earth's total albedo (Law and Stohl, 2007; IPCC, 2007). A recent study (Hadley and Kirchstetter, 2012) generated and characterized pure and black carbon-laden snow in the laboratory and verified that black carbon contamination appreciably reduces the snow albedo, at levels that have been found in natural settings (Forsström et al., 2009; Aamaas et al., 2011). Clarke and Noone (1985) found that for a mass fraction of $10-40 \mathrm{ng} \mathrm{g}^{-1}$ soot, the snow albedo is reduced by $1-3 \%$ in fresh snow and by a factor of 3 as the snow ages and the lightabsorbing particles become more concentrated. Doherty et al. (2010) estimated the black carbon concentrations in snow for regions near the Arctic at 4-20 $\mathrm{ng} \mathrm{g}^{-1}$, with an expected albedo reduction of $1-2 \%$.

The determination of optical parameters as a function of wavelength has been recently recognized as an efficient way to distinguish between various aerosol types. For example, Rosen et al. (1979) measured $\alpha_{\mathrm{a}}=1.0$ for urban aerosol, Bond (2001) studied the spectral dependence of visible light absorption by carbonaceous particles emitted from coal combustion and found a strong spectral dependency, $1.0<\alpha_{\mathrm{a}}<2.9$, and Mogo et al. (2005) made similar measurements in a coastal site in Southern Spain and found that $0.2<\alpha_{\mathrm{a}}<2.0$ for the visible range of the spectrum and that $0.2<\alpha_{\mathrm{a}}<2.5$ for the UV range. High spectral resolution data are also presented for this campaign in ALOMAR by Montilla et al. (2011). $\alpha_{\mathrm{s}}$ can be used to infer information regarding the size of the particles as it relates inversely to particle size (Russell et al., 2010). Pereira et al. (2011) observed $\alpha_{\mathrm{s}}=1.4$ for aerosols dominated by sub-micrometer particles, and Collaud Coen et al. (2004) observed $\alpha_{\mathrm{s}}$ to be lower than 0.5 during Saharan dust events measured at Jungfraujoch. The wavelength dependence of $\omega_{0}$ is also influenced by various aerosol species. Dubovik et al. (2002) found that for urban-industrial aerosols and biomass burning, $\omega_{0}$ decreases with increasing wavelength, whereas for desert dust, $\omega_{0}$ increases with increasing wavelength (Collaud Coen et al., 2004). This wavelength dependence inversion can be explained by the greater size of the particles of desert dust, causing the scattering process to be dominated by geometric processes that are wavelength independent. Furthermore, some dust particles (such as hematite) are strong absorbers, and the increase of absorption together with the decrease of scattering can also contribute to the change of the slope of $\omega_{0}$ from positive to negative. 
In addition, measurement of the number size distribution can be used to infer the aerosol sources. For example, the presence of coarse modes can be due to mechanical generation processes, and the presence of ultrafine modes can be due to the formation of new particles. For a given location, this information is useful for understanding the local aerosol and its relation to the sampled air mass. Previous works (Birmili et al., 2001; Tunved et al., 2005) have observed that different size distribution properties can be related to the origin of the air masses, with similar distributions often arriving from the same origin.

The present work was conducted within the framework of a larger intensive aerosol characterization campaign conducted at Andenes, a remote site located in northern Norway, during the summer of 2008. During the summer, the region provides an excellent environment for studying remote background aerosols (those containing natural compounds, such as sea salt and sulfuric acid, and anthropogenic pollutants, such as soot, resulting from transport to the region), as there are few local sources of anthropogenic particles. The campaign was conducted by the Atmospheric Optics Group of Valladolid University as part of the International Polar Year through the POLARCAT project, and the main goal of the campaign was to comprehensively characterize the local aerosols. Several instruments for aerosol characterization were employed simultaneously, and the results from aerosol absorption and scattering measurements, as well as the number size distributions, are presented. We analyzed also the absorption/scattering coefficients, $\sigma_{\mathrm{a}, \mathrm{s}}$, and their Ångström exponents, $\alpha_{\mathrm{a}, \mathrm{s}}$, together with the single-scattering albedo.

The main purpose of this paper is to present an analysis of the collected optical and microphysical data. The particle number size distributions were used to study some basic relationships with the optical properties. Source areas were assessed by identifying the origins of air masses that relate to different levels of scattering, absorption and number size distributions in Andenes.

Whereas columnar aerosol properties are presented in Toledano et al. (2006), Rodríguez et al. (2011) and Rodríguez et al. (2012), no surface measurements appear to have been reported for the in situ properties of aerosols in our study area. The site belongs to the AERONET network, and therefore, the columnar aerosol data are also readily available (Rodríguez et al., 2011) and were used as complementary information.

\section{Methods}

\subsection{Site description}

The ALOMAR (Arctic Lidar Observatory for Middle Atmosphere Research) station is located in Andøya island close to the town of Andenes ( $69^{\circ} 16^{\prime} \mathrm{N}, 16^{\circ} 00^{\prime} \mathrm{E}, 380 \mathrm{~m}$ a.s.l.) on the Atlantic coast of Norway, approximately $300 \mathrm{~km}$ north of the Arctic Circle, Fig. 1. The facility is managed by the Andøya Rocket Range, and the site is well-suited for measurements of remote background aerosols due to the absence of large regional pollution sources. From the end of May to the end of July, the sun is above the horizon for $24 \mathrm{~h}$ each day, with a maximum elevation during the solstice of $42^{\circ}$ at noon and $2^{\circ}$ at midnight. Despite being located north of the Arctic Circle, the station is considered sub-arctic due to the climate of the region. The climate is strongly influenced by the Gulf Stream, which provides mild temperatures during the entire year; average temperatures are $-2{ }^{\circ} \mathrm{C}$ in January and $11^{\circ} \mathrm{C}$ in July. Rapid variations in temperature can occur in the summer months, from $4^{\circ}$ to $30^{\circ} \mathrm{C}$. During our measurement period, the daily average temperature was $7.1^{\circ} \mathrm{C}$, with a minimum of $2.5^{\circ} \mathrm{C}$ (15 June), a maximum of $15.4^{\circ} \mathrm{C}$ (20 July) and a standard deviation of $2.9^{\circ} \mathrm{C}$. The relative humidity level was high across the study period, with an average of $92.8 \%$. The minimum humidity level was $62 \%$, the maximum humidity level was $100 \%$ and the standard deviation was $9.0 \%$. The surface wind pattern was oriented mainly south-southwest (27\% of occurrences), but an eastnortheast component was also frequently registered $(22 \%)$. Other frequent wind directions were south-southeast (16\%), west-southwest (15\%) and east-southeast (13\%). The average wind speed was $5.6 \mathrm{~km} \mathrm{~h}^{-1}$ (with a minimum, maximum and standard deviation of $2.1,13.1$ and $2.4 \mathrm{~km} \mathrm{~h}^{-1}$, respectively). Further details regarding the measurement station can be found in Skatteboe (1996) and Toledano et al. (2006).

\subsection{Instrumentation}

Aerosol samples were obtained from a stainless steel inlet protected with a rain cap and a metal screen designed to exclude insects. The inlet of the sampling line was approximately $2 \mathrm{~m}$ above the roof of the measurement station building, which was approximately $7 \mathrm{~m}$ above the ground. The cut-off diameter of the inlet nozzle and sample transport line was approximately $10 \mu \mathrm{m}$. The sampled air was heated when necessary to achieve a low relative humidity of $40 \%$ prior to entering the instruments. Airflow through the sampling line was divided into several separate flows and directed toward individual instruments. The flow into each instrument was measured once a day using an electronic bubble flowmeter (Gilibrator system, Gilian).

The light absorption coefficients were measured at three wavelengths (470, 522 and $660 \mathrm{~nm})$ using a particle soot absorption photometer (PSAP, Radiance Research) at a flow set to $1.51 \mathrm{~min}^{-1}$. The instrument uses a filter-based technique in which aerosols are continuously deposited onto a glass fiber filter at a known flow rate. The change in the transmitted light is related to the optical absorption coefficient using Beer's law. The instrument is an improved version of the integrating plate method (Lin et al., 1973) and is described in detail by Bond et al. (1999) and Virkkula et al. (2005). The detection limit of the instrument was investigated by Springston 


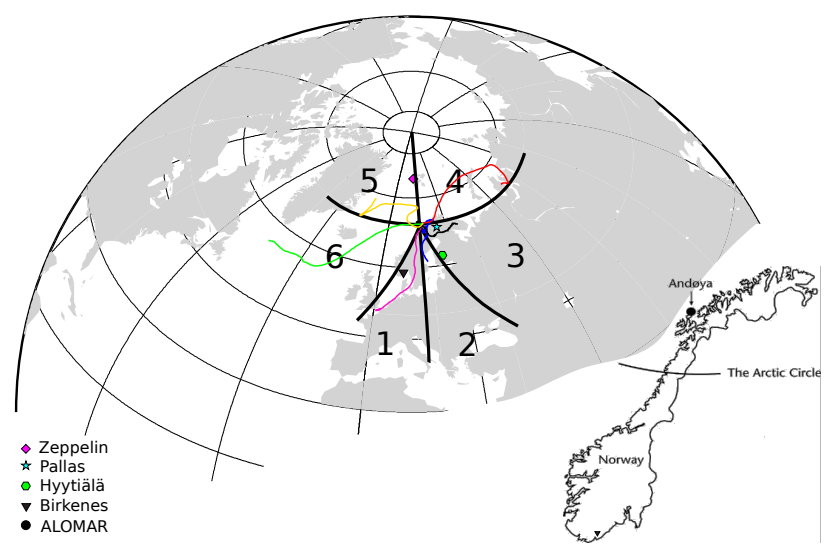

Fig. 1. Location of the ALOMAR station in Northern Norway. The classification sectors of back trajectory air masses are displayed and also the typical trajectories for each air mass origin classification (colored lines).

and Sedlacek III (2007) and Müller et al. (2011) and for an averaging time of $60 \mathrm{~s}$, the expected value approaches $0.05 \mathrm{Mm}^{-1}$.

The scattering and backscattering coefficients were measured at three wavelengths $(450,550$ and $700 \mathrm{~nm})$ using an integrating nephelometer (model 3563, TSI) at a flow rate of $461 \mathrm{~min}^{-1}$. The instrument is described in detail by Anderson et al. (1996) and Anderson and Ogren (1998). Calibration was conducted twice per month using $\mathrm{CO}_{2}$ as the highspan gas and filtered air as the low-span gas. The averaging time was set to $1 \mathrm{~min}$. The zero signal was measured once per hour. The data was corrected for truncation errors according to Anderson and Ogren (1998). For the 1-min averages, the detection limits for the scattering coefficients were $0.65,0.25$ and $0.38 \mathrm{Mm}^{-1}$ for 450,550 and $700 \mathrm{~nm}$, respectively (Anderson et al., 1996).

The number size distributions of dry particles were measured separately for the fine and coarse fractions using a scanning mobility particle sizer (SMPS) and an aerodynamic particle sizer (APS, model 3321, TSI), respectively. The SMPS consists of a differential mobility analyzer (model 3080, TSI) and a condensation particle counter (CPC model $3022 \mathrm{~A}, \mathrm{TSI})$ and was operated at a flow rate of $1.51 \mathrm{~min}^{-1}$. The size range for particle number detection was set to $\sim 10$ $390 \mathrm{~nm}$ (mobility diameter). The quality of the SMPS measurements depends essentially on the stability of the air flow rates and the performance of the CPC (Wiedensohler et al., 2012). According to the manufacturer, the latter has a counting efficiency of $100 \%$ for particles above $50 \mathrm{~nm}$ and above $80 \%$ for particles above $10 \mathrm{~nm}$. An intercomparison of our instrumental system was carried out before the campaign and the SMPS distributions obtained remained within the manufacturer uncertainties $( \pm 10 \%)$. The APS was operated at a flow rate of $51 \mathrm{~min}^{-1}$, and it was set up to detect the number concentration of particles in the size range from
0.5 up to $20 \mu \mathrm{m}$ (aerodynamic diameter). However, our inlet system had a cut-off diameter of $10 \mu \mathrm{m}$. The APS lowest detectable concentration is $0.001 \mathrm{~cm}^{-3}$ and for solid particles, counting efficiencies range from $85 \%$ to $99 \%$ (Volckens and Peters, 2005). The total particle concentration in the range 3-10 $000 \mathrm{~nm}$ was monitored using an ultrafine condensation particle counter (model 3776, TSI). According to the manufacturer, this instrument detects particles as small as $2.5 \mathrm{~nm}$ with counting efficiency of $100 \%$ for particles above $3 \mathrm{~nm}$ (accuracy $\pm 10 \%$ ). It was operated in high-flow mode $\left(1.51 \mathrm{~min}^{-1}\right)$ to minimize diffusion losses.

The upper boundary of the size range for the SMPS data was selected to be $390 \mathrm{~nm}$ to achieve a better resolution for the lower particle size channels, allowing us to study possible new particle formation events. This decision, together with the low concentration of particles registered by the APS, prevented us from merging the SMPS and APS data because the gap between the upper channel of the SMPS, $390 \mathrm{~nm}$, and the lower channel of the APS, $500 \mathrm{~nm}$, would require interpolation between these sizes and a conversion of the aerodynamic diameters provided by the APS to the mobility diameters provided by the SMPS, with associated errors resulting from both procedures.

\subsection{Data processing}

The averaging time used for the PSAP was $60 \mathrm{~s}$, and the filter was replaced whenever the amount of transmitted light reached $70 \%$ of the initial intensity. The response of the instrument depends on the loading of particles on the filter, the amount of light scattered by the particles, the flow rate and the spot size (Bond et al., 1999; Virkkula et al., 2005). The data were corrected for these dependencies using the procedure described by Bond et al. (1999) since the algorithms presented by Bond et al. (1999) and Virkkula et al. (2005) agreed with the high $\omega_{0}$ and small $\sigma_{\mathrm{a}}$ values and as no other values of $\sigma_{\mathrm{a}}>6 \mathrm{Mm}^{-1}$ were observed at the ALOMAR station during the measurement period. The corrected aerosol absorption coefficients at 470, 522 and $660 \mathrm{~nm}$ were extrapolated to the working wavelengths of the nephelometer, i.e., 450, 550 and $700 \mathrm{~nm}$, using the Ångström exponent.

The values obtained for backscattering turned out to be below the error threshold and are not presented.

To investigate the wavelength dependence of $\sigma_{\mathrm{a}, \mathrm{s}}$, we calculated the absorption/scattering Ångström exponent. This parameter is commonly used when conducting a more detailed analysis of the variations of the spectral shape of $\sigma_{\mathrm{a}, \mathrm{s}}$ and is defined as the negative slope of the logarithm of the absorption coefficient as a function of wavelength. It is given by:

$\sigma_{\mathrm{a}, \mathrm{s}}=K \lambda^{-\alpha_{\mathrm{a}, \mathrm{s}}}$.

In practice, we calculated $\alpha_{\mathrm{a}, \mathrm{s}\left(\lambda_{1}, \lambda_{2}, \ldots, \lambda_{n}\right)}$ for more than two wavelengths through the logarithmic fit of Eq. (1), and we calculated $\alpha_{\mathrm{a}, \mathrm{s}\left(\lambda_{1}, \lambda_{2}\right)}$ for a pair of wavelengths, $\lambda_{1}, \lambda_{2}$, 
according to the following simplified formula:

$$
\alpha_{\mathrm{a}, \mathrm{s}}=-\frac{\log \left(\sigma_{\mathrm{a}, \mathrm{s}}\left(\lambda_{2}\right) / \sigma_{\mathrm{a}, \mathrm{s}}\left(\lambda_{1}\right)\right)}{\log \left(\lambda_{2} / \lambda_{1}\right)} .
$$

The aerosol size distribution observations were made on the timescale of minutes, and twelve measurements were conducted per hour. For the SMPS, we describe the total concentration and the concentrations $N_{30-50}=\sum_{30}^{50} n_{i}$, $N_{50}=\sum_{50}^{390} n_{i}$ and $N_{100}=\sum_{100}^{390} n_{i}$, where $n_{i}$ is the measured aerosol number concentration in the size interval considered. The cut-off diameters of 30,50 and $100 \mathrm{~nm}$ were selected according to the criteria presented by Asmi et al. (2011). The nucleation, Aitken and accumulation modes are also fully described. For the APS, we describe the shape of the distribution and the total concentration. For the UCPC instrument, the total concentration is presented.

Data from 13 June to 26 August 2008 were available. The statistical data for all instruments were calculated based on the hourly averages, which appeared reasonable given the low values observed. The hourly averages were preferred over the daily averages because they were more sensitive to local effects, whereas the daily averages were more useful in identifying external long-range effects. The hourly value was accepted when six or more 5-min values were available. The overall data coverage was approximately $72 \%$ due to the weather conditions (measurements taken during rainfall were typically below the detection limit of the instruments and were thus eliminated), and this value is considered adequate for determining the main features of optical properties and concentrations of the aerosols.

For the derived optical quantities, a quadrature sum of errors yielded relative uncertainties at the $95 \%$ confidence level of $\pm 15 \%, \pm 45 \%, \pm 10 \%$, and $\pm 34 \%$, respectively for $\omega_{0}, \alpha_{\mathrm{a}}, \alpha_{\mathrm{s}}$ and $\alpha_{\omega_{0}}$.

\subsection{Determination of air mass origins by back trajectory analysis}

To analyze the source and transport pathways of the air masses arriving at ALOMAR, a back trajectories analysis was conducted covering the period of measurement using NOAA's HYSPLIT model (Draxler and Rolph, 2003; Rolph, 2003). The back trajectories were calculated typically $120 \mathrm{~h}$ backwards in time at an arrival height of $500 \mathrm{~m}$ above ground level at 12:00 UTC. The model runs were constructed using the GDAS (Global Data Assimilation System) meteorological archive, and the vertical velocity of the model as vertical motion (3-dimensional) was selected. The altitude level of $500 \mathrm{~m}$ was used for the classification because it is within the boundary layer, where most of the particles are confined. However, higher altitude trajectories were also used in the investigation of the long-range transport episodes. To relate the air masses to the source of the newly formed particles, the mixed layer depth was also obtained from the HYSPLIT model, and the air mass for new particle formation event days was considered as a source of the aerosol particles that arrived and formed close to the measurement point if the $500 \mathrm{~m}$ air mass was inside the boundary layer for the majority of the time.

Figure 1 shows the demarcation of six geographical sectors of different air mass types influencing the measurement site: 1(S), 2(SE), 3(E), 4(NNE), 5(NW) and 6(W). The air mass sector classification is based on the longest residence time of the trajectories in each geographical sector. This methodology has been described in detail in previous studies (Rodríguez et al., 2011; Toledano et al., 2009), and a full study on back trajectories in Andenes was conducted by Rodríguez et al. (2011) and Rodríguez et al. (2012). In Fig. 1, we also present typical trajectories for each air mass origin classification. The purpose is to provide visualization of the source region and to display the distance that the air mass traveled during the $120 \mathrm{~h}$ prior to the measurement.

To study the influence of the transport pathways of the air masses on the aerosol properties observed at the ALOMAR station, the data were divided in six separate groups according to the origin sector of the air mass, and the aerosol data were then correlated with each sector membership. The most common air masses were those from the north, sectors $4(31 \%)$ and $5(27 \%)$, and from the west, sector $6(22 \%)$, arriving from the ocean. The other air masses originated in the south, sectors $1(5 \%)$ and $2(3 \%)$, and in the east, sector 3 $(12 \%)$, which arrived from Great Britain, Scandinavia, eastern Europe and Russia in most cases. Rodríguez et al. (2011) found that sectors 1, 2 and 3 were related to high-pressure systems that had been located over the Scandinavian Peninsula and Siberia, resulting in sunny and dry weather over the region. Sector 4 was characterized by cold and dry air masses from the Arctic sea. Sectors 5 and 6 were associated with low-pressure systems, and precipitation was frequent when air masses arrived from these sectors. Rodríguez et al. (2011) and Rodríguez et al. (2012) also concluded that the most frequent air mass origin was the northwest and west (North Atlantic Ocean). These works suggested that the site location and the local aerosols largely determined the aerosol type, with low aerosol concentration dominated by fine particles. They observed that the low aerosol background is episodically altered by turbid air masses, which mainly originate in central and eastern Europe, with transport of anthropogenic pollution, smoke from biomass burning and in some cases Saharan dust.

Based on the sector classification of each identified transport pathway, we established a relationship between the air mass origin and the parameters we measured. The mean frequency of occurrence of the transport sectors and its relationship with the aerosol parameters are summarized in Fig. 8. 
Table 1. Evaluation of the overall ranges and arithmetic mean values of the absorption/scattering coefficients, the Ångström exponents, the single scattering albedo and the concentrations in each size section obtained from the data set measured at ALOMAR. $P_{x}$ values are the x-th percentage of the considered parameter. The median value $\left(P_{50}\right)$ is listed in bold.

\begin{tabular}{|c|c|c|c|c|c|c|c|c|c|}
\hline & & Mean & $\mathrm{StD}$ & Range & $P_{16}$ & $P_{25}$ & $P_{50}$ & $P_{75}$ & $P_{84}$ \\
\hline \multirow{3}{*}{$\sigma_{\mathrm{s}}\left(\mathrm{Mm}^{-1}\right)$} & $450 \mathrm{~nm}$ & 7.31 & 4.79 & $0.29-31.24$ & 3.08 & 3.63 & 6.58 & 9.55 & 11.68 \\
\hline & $550 \mathrm{~nm}$ & 5.41 & 3.55 & $0.25-23.21$ & 2.23 & 2.76 & 4.75 & 7.12 & 8.54 \\
\hline & $700 \mathrm{~nm}$ & 4.08 & 2.84 & $0.19-18.95$ & 1.54 & 2.09 & 3.39 & 5.32 & 6.49 \\
\hline$\alpha_{\mathrm{s}}(450-750)$ & & 1.37 & 0.61 & $0.20-3.07$ & 0.68 & 0.82 & 1.36 & 1.90 & 2.06 \\
\hline \multirow{3}{*}{$\sigma_{\mathrm{a}}\left(\mathrm{Mm}^{-1}\right)$} & $450 \mathrm{~nm}$ & 0.45 & 0.33 & $0.14-2.72$ & 0.22 & 0.24 & 0.35 & 0.53 & 0.64 \\
\hline & $550 \mathrm{~nm}$ & 0.40 & 0.27 & $0.13-2.28$ & 0.20 & 0.23 & 0.32 & 0.48 & 0.57 \\
\hline & $700 \mathrm{~nm}$ & 0.36 & 0.23 & $0.12-1.92$ & 0.19 & 0.21 & 0.30 & 0.43 & 0.51 \\
\hline$\alpha_{\mathrm{a}}(450-750)$ & & 0.40 & 0.21 & $0.01-0.97$ & 0.19 & 0.25 & 0.39 & 0.55 & 0.61 \\
\hline \multirow{3}{*}{$\omega_{0}$} & $450 \mathrm{~nm}$ & 0.93 & 0.04 & $0.60-0.99$ & 0.89 & 0.91 & 0.94 & 0.96 & 0.96 \\
\hline & $550 \mathrm{~nm}$ & 0.91 & 0.05 & $0.62-0.99$ & 0.87 & 0.89 & 0.92 & 0.95 & 0.96 \\
\hline & $700 \mathrm{~nm}$ & 0.89 & 0.06 & $0.50-0.99$ & 0.83 & 0.86 & 0.90 & 0.94 & 0.96 \\
\hline$\alpha_{\omega_{0}}(450-750)$ & & 0.09 & 0.09 & $-0.11-0.95$ & 0.01 & 0.02 & 0.07 & 0.14 & 0.17 \\
\hline$N_{30-50}$ & & 258 & 355 & $3-2970$ & 27 & 45 & 127 & 315 & 449 \\
\hline$N_{50}$ & & 469 & 516 & $2-4001$ & 81 & 126 & 266 & 615 & 892 \\
\hline$N_{100(\text { accumulation })}$ & $\left(\# / \mathrm{cm}^{3}\right)$ & 183 & 209 & $0-2226$ & 34 & 61 & 114 & 224 & 317 \\
\hline$N_{\text {Aitken }}(30-100 \mathrm{~nm})$ & & 545 & 647 & $5-4460$ & 68 & 111 & 308 & 711 & 1023 \\
\hline$N_{\text {nucleation }}(10-30 \mathrm{~nm})$ & & 549 & 1070 & $1-10131$ & 29 & 53 & 185 & 488 & 881 \\
\hline$N_{\text {submicrometer }}(10-390 \mathrm{~nm})$ & & 1277 & 1563 & $15-14111$ & 190 & 291 & 710 & 1635 & 2376 \\
\hline$N_{\text {micrometer }}(>500 \mathrm{~nm})$ & $\left(\# / \mathrm{cm}^{3}\right)$ & 1 & 1 & $0-12$ & 0 & 1 & 1 & 2 & 3 \\
\hline$N_{\text {total }}(>3 \mathrm{~nm})$ & $\left(\# / \mathrm{cm}^{3}\right)$ & 2463 & 4251 & $5-66772$ & 293 & 500 & 1175 & 2895 & 4113 \\
\hline
\end{tabular}

\section{Results and discussion}

\subsection{Temporal variations in aerosol optical properties}

During our observations, the hourly mean $\sigma_{\mathrm{s}}$ at 450,550 and $700 \mathrm{~nm}$ ranged from 0.29 to $31.24 \mathrm{Mm}^{-1}, 0.25$ to $23.21 \mathrm{Mm}^{-1}$ and 0.19 to $18.95 \mathrm{Mm}^{-1}$ (average $7.31,5.41$ and $4.08 \mathrm{Mm}^{-1}$ with standard deviations of $4.79,3.55$ and $\left.2.84 \mathrm{Mm}^{-1}\right)$, respectively. The hourly mean values of $\sigma_{\mathrm{a}}$ at $450 \mathrm{~nm}, 550 \mathrm{~nm}$ and $700 \mathrm{~nm}$ ranged from 0.14 to $2.72 \mathrm{Mm}^{-1}$, 0.13 to $2.28 \mathrm{Mm}^{-1}$ and 0.12 to $1.92 \mathrm{Mm}^{-1}$ (average 0.45 , 0.40 and 0.36 with standard deviations of $0.33,0.27$ and $0.23 \mathrm{Mm}^{-1}$ ), respectively. For both parameters, the median value was lower than the mean. The range of the values of $\sigma_{\mathrm{s}}$ was ten times larger than the range of the values of $\sigma_{\mathrm{a}}$. Statistical data regarding the $\sigma_{\mathrm{s}}$ and $\sigma_{\mathrm{a}}$ values are presented in Table 1, and a time series representing over 70 days of measurement is shown in Fig. 2.

1166 hourly means were available for $\sigma_{\mathrm{s}}$, and 1046 were available for $\sigma_{\mathrm{a}}$, which allowed for the calculation of 883 hourly values of $\omega_{0}$. The frequency histogram of $\sigma_{\mathrm{s}}, \sigma_{\mathrm{a}}$ and $\omega_{0}$ at $550 \mathrm{~nm}$, shown in Fig. 3, presents only one frequency mode, centered at $3 \mathrm{Mm}^{-1}, 0.3 \mathrm{Mm}^{-1}$ and 0.95 , respectively, for each parameter. Although the magnitude of $\sigma_{\mathrm{s}}$ and $\sigma_{\mathrm{a}}$ depend on many factors, our results, when compared with the literature values for other areas and Table 1, suggest that the magnitude of the aerosol scattering/absorption coefficients at ALOMAR were comparable to those in other polar regions, such as those presented by Delene and Ogren (2002) and Quinn et al. (2007) at Barrow and Aaltonen et al. (2006) at Pallas.

Correspondingly, the hourly mean values of the $\omega_{0}$ parameter measured at ALOMAR presented average values of 0.93 , 0.91 and 0.89 at $450 \mathrm{~nm}, 550 \mathrm{~nm}$ and $700 \mathrm{~nm}$, respectively. Values ranged from 0.60 to $0.99,0.62$ to 0.99 and 0.50 to 0.99 , respectively (see Fig. 2 and Table 1). The lowest value registered was $0.62(550 \mathrm{~nm})$; but, in fact, $\omega_{0}$ was observed to vary mainly between 0.80 and 0.99 , as seen in Fig. 2 and confirmed by the value of the median, 0.92 , and the first quartile, $P_{25}, 0.89(550 \mathrm{~nm})$ (see also Fig. 3). These values lie in the range presented for polar regions by several authors as compiled by Tomasi et al. (2007).

The measured spectral series of $\sigma_{\mathrm{s}}$ and $\sigma_{\mathrm{a}}$ were used to derive the corresponding values of the scattering and absorption Ångström exponents following the best-fit procedure based on Eq. (1). The Ångström exponents calculated for the $450 \mathrm{~nm} / 700 \mathrm{~nm}$ wavelength pairs lay in the range between 0.20 and 3.07 for scattering and in the range between 0.01 and 0.97 for absorption. The observation of $\alpha_{\mathrm{a}}$ values below 1 
(a)

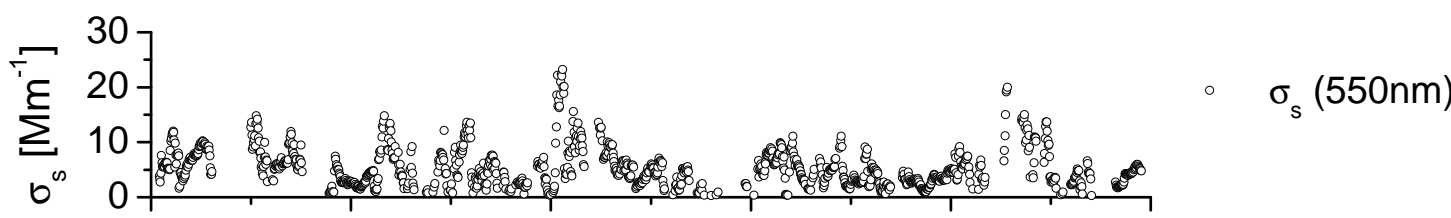

(b)

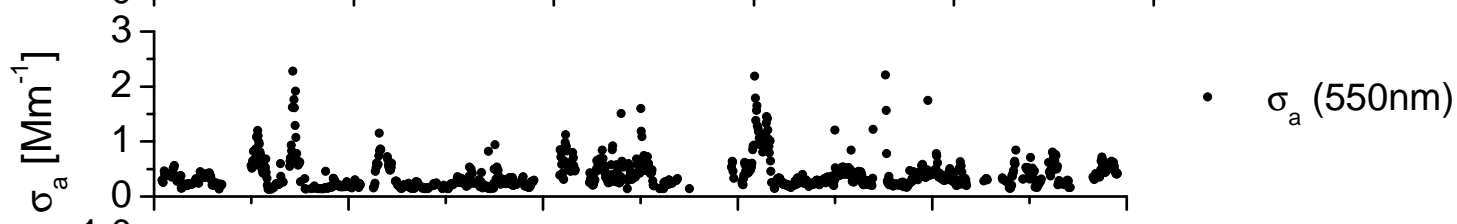

(c)

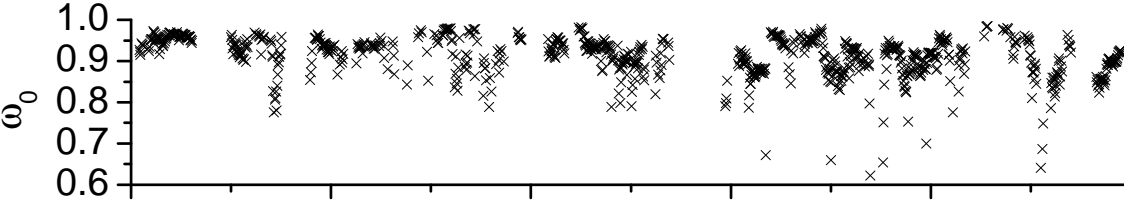

(d)

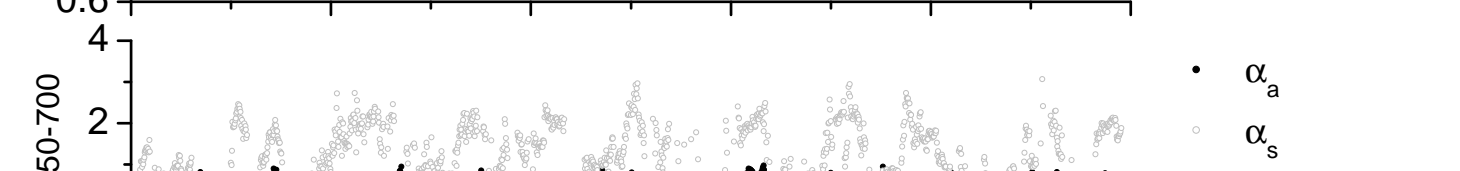

(e)

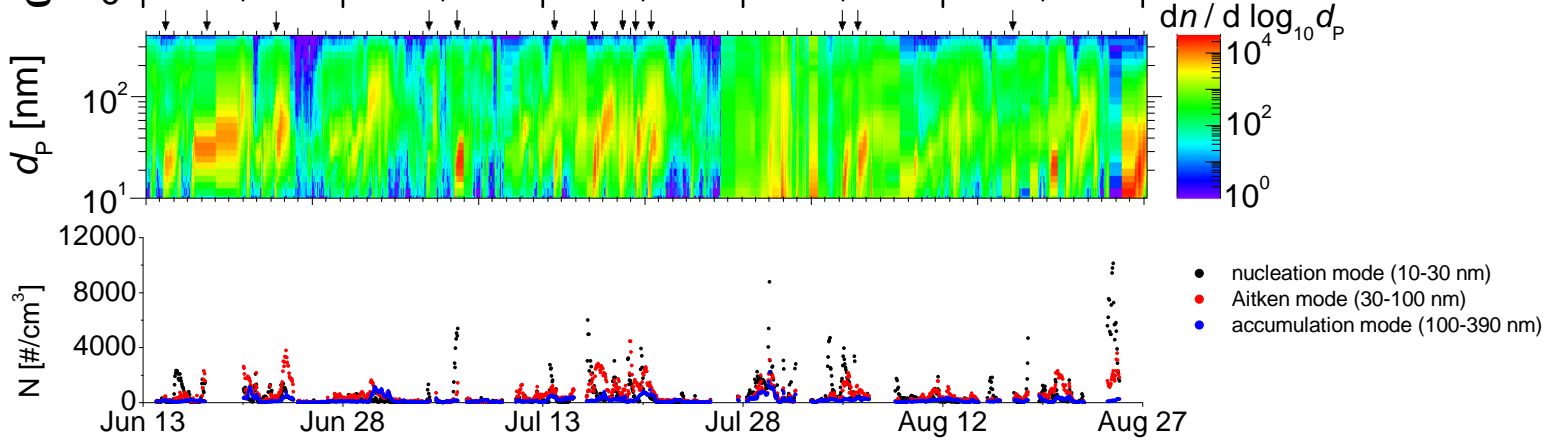

Fig. 2. (a, b, c, d) Time-series of hourly average values of the $\sigma_{\mathrm{s}}, \sigma_{\mathrm{a}}, \omega_{0}, \alpha_{\mathrm{s}}$ and $\alpha_{\mathrm{a}}$. (e) Particle number size distributions measured for the submicrometer particles. Color scale indicates the number of particles in each size. (f) Temporal variation of the concentration of nucleation, Aitken and accumulation modes. The arrows indicate the occurrence of new particle formation events (periods of kind (3) as described in the text). All other concentration increases, not marked with arrows, correspond to periods of type (2). The remaining situations are clean conditions, situation (1).

is an interesting characteristic of the local absorbent particles and has previously been presented by Montilla et al. (2011), who measured continuous spectra of aerosol absorption coefficients in the wavelength range of $320-800 \mathrm{~nm}$ and obtained the $\alpha_{\mathrm{a}}$ exponents for different spectral ranges, including the UV range. Statistical properties of the hourly mean values of $\alpha_{\mathrm{s}, \mathrm{a}}$ are presented in Table 1 and show mean values of 1.37 and 0.40 , respectively. In both cases, the median value is lower than the mean. The standard deviations are 0.61 and 0.21 , respectively. Figure $2 \mathrm{~d}$ shows the hourly mean Angström exponent values for the $450 \mathrm{~nm} / 700 \mathrm{~nm}$ wavelength pair covering the entire measurement period.

The frequency histograms of $\alpha_{\mathrm{s}}$ and $\alpha_{\mathrm{a}}$ are shown in Fig. 3d, e. The histogram for $\alpha_{\mathrm{a}}$ presents only one frequency mode, centered at 0.35 , whereas the histogram for $\alpha_{\mathrm{s}}$ presents two modes, centered at 0.7 and 1.9. Whereas the absorption Ångström exponent lies in the range presented for other polar regions (Tomasi et al., 2007; Aaltonen et al., 2006), the scattering Ångström exponent presents a few high values that are more typical of sites affected by urban or continental pollution (Vrekoussis et al., 2005; Lyamani et al., 2008). These values may be due to long-range transport episodes from Central Europe and Russia. In Fig. 1, the trajectory of the air mass arriving from sector 3 (day 14 July - black line) is presented as an example of transport from Russia. The $\sigma_{\mathrm{s}}$ and $\sigma_{\mathrm{a}}$ values at $550 \mathrm{~nm}$ were $8.36 \mathrm{Mm}^{-1}$ and $0.67 \mathrm{Mm}^{-1}$, respectively, while the $\alpha_{\mathrm{s}}$ and $\alpha_{\mathrm{a}}$ values were 2.10 and 0.37 , respectively. For the sample trajectory arriving from sector 2 (blue line), $\sigma_{\mathrm{s}}$ and $\sigma_{\mathrm{a}}$ reached values of $9.53 \mathrm{Mm}^{-1}$ and $0.61 \mathrm{Mm}^{-1}$, respectively, and the $\alpha_{\mathrm{s}}$ and $\alpha_{\mathrm{a}}$ values were 2.01 and 0.44 , respectively. A sample trajectory arriving from Belgium (day 2 June - magenta line) is presented for sector 1 . The $\sigma_{\mathrm{s}}$ and $\sigma_{\mathrm{a}}$ parameters reached values of $11.48 \mathrm{Mm}^{-1}$ and $0.74 \mathrm{Mm}^{-1}$, respectively, and the $\alpha_{\mathrm{s}}$ and $\alpha_{\mathrm{a}}$ values were 



Fig. 3. Frequency histogram for the (a) $\sigma_{\mathrm{S}}$, (b) $\sigma_{\mathrm{a}}$, (c) $\omega_{0}$, (d) $\alpha_{\mathrm{S}}$ and (e) $\alpha_{\mathrm{a}}$.

1.88 and 0.33 , respectively. The sample events presented for sectors 1, 2 and 3 are characterized by small particles with higher absorption and scattering than the average. These events confirm the transport of anthropogenic aerosols from the mid-latitudes into the sub-Arctic area, as already registered by Rodríguez et al. (2012).

The maximum mean values of $\sigma_{\mathrm{a}}$ and $\sigma_{\mathrm{s}}$ were observed for sector $2(\mathrm{SE})$ and were 0.61 and $9.53 \mathrm{Mm}^{-1}$, respectively. The minimum mean values of $\sigma_{\mathrm{a}}$ and $\sigma_{\mathrm{s}}$ were observed for sector 4 (NNE) and were 0.29 and $3.90 \mathrm{Mm}^{-1}$, respectively. The mean $\omega_{0}$ parameter ranges from 0.89 (when the air masses came from sector 3 (E)) to 0.94 (when the air masses came from sector 2 (SE)). A similar behavior is presented by $\alpha_{\mathrm{a}}$ and $\alpha_{\mathrm{s}}$, for which the maximum mean values were observed in sector 2 ( 0.44 and 2.01 , respectively). The minimum mean value of $\alpha_{\mathrm{a}}, 0.24$, was observed for sector 5 (NW), whereas the minimum mean $\alpha_{\mathrm{s}}, 0.79$, was observed for sector 4 (NNE). The mean value of $\alpha_{\omega_{0}}$ ranges from 0.03 for sector 4 to 0.13 for sector 1 (S). See Fig. 8 .
We also analyzed the spectral dependence of the singlescattering albedo because this parameter, $\alpha_{\omega_{0}}$, is known to be very sensitive to the composition of the particles. For the $450 \mathrm{~nm} / 700 \mathrm{~nm}$ wavelength pair, $\alpha_{\omega_{0}}$ was found to range between -0.11 and 0.95 (with a mean value and a standard deviation of 0.09). The high standard deviation of this parameter within its range of values indicates that a large variety of aerosol types is present at ALOMAR during the summer. The observed negative values are due to desert aerosol air masses that reach the ALOMAR station. These rare events, arriving from North Africa, are usually weak and of short duration, since desert aerosols have to travel across Europe to reach the ALOMAR station. One or two of these events, of 1-2 days in duration, are observed every summer (Rodríguez et al., 2011). These events were confirmed by data from the CIMEL sun photometer (part of the AERONET network) located at the station. If the daily aerosol optical depth exceeds a threshold value (given by the annual mean plus one standard deviation) and the extinction Ångström exponent is lower than 1.1, the day is classified as possible aerosol dust event (Rodríguez et al., 2011). The back trajectories and MODIS images are then analyzed to confirm the dust events. Unfortunately, only very weak dust events were observed during the period reported in this paper and the potential dust that arrived at the station was always mixed with pollution or other particles making it difficult to track down the exact source. However, in August 2007 our group detected the presence of coarse dust aerosol particles in Andenes and that event is reported and fully analyzed in Rodríguez et al. (2012) (the dust aerosol optical depth provided by the NAAPS model, the aerosol optical depth and the Ångström exponent provided by the Cimel sun photometer and the MODIS-Terra sensor are presented in that work for the days of the event).

\subsection{Particle number concentrations in various size ranges}

In this section, we first independently present the characteristics of each particle size range and then analyze the relations between these ranges.

The average hourly concentration for the submicrometer particles (10-390 nm) was $1277 \mathrm{~cm}^{-3}$, with a standard deviation of $1563 \mathrm{~cm}^{-3}$. The average value for the concentration of micrometer-sized aerosols $(0.5-10 \mu \mathrm{m})$ was $1 \mathrm{~cm}^{-3}$, with a standard deviation of $1 \mathrm{~cm}^{-3}$. The average number concentration measured for the total range $(3-10000 \mathrm{~nm})$ is $2463 \mathrm{~cm}^{-3}$, with a standard deviation of $4251 \mathrm{~cm}^{-3}$. The submicrometer range is further investigated for the ranges $30-50,50-390$ and $100-390 \mathrm{~nm}$. The average number concentrations and their standard deviations are $258 \mathrm{~cm}^{-3}\left(355 \mathrm{~cm}^{-3}\right), 469 \mathrm{~cm}^{-3}\left(516 \mathrm{~cm}^{-3}\right)$ and $183 \mathrm{~cm}^{-3}$ $\left(209 \mathrm{~cm}^{-3}\right)$, respectively. The concentration percentiles are tabulated with their respective mean values in Table 1. ALOMAR has slightly higher results for the aerosol number concentration in the size sections $N_{30-50}$ and $N_{50}$ but slightly 
smaller concentrations for $N_{100}$ than those measured in the sampling study of Asmi et al. (2011) conducted at the Pallas station, which is located at almost the same latitude as ALOMAR but in a remote continental area in Northern Finland. It should be stressed however, that our concentration $N_{100}$ comprises the size range $100-390 \mathrm{~nm}$, whereas that of Asmi's comprises a broader size range $(100-500 \mathrm{~nm})$. The number size distribution level exhibits the same range of values for the section $N_{30-50}$ at ALOMAR as at Birkenes, which is located in Southern Norway, but the values recorded at Birkenes for $N_{50}$ and $N_{100}$ are almost twice those registered at ALOMAR. However, the number size distributions across all sections at the Arctic station of Zeppelin, located in the Svalbard Islands, are half of the values recorded at ALOMAR.

A plot of the particle number size distributions measured for the submicrometer particles is presented in Fig. 2e,f and illustrates the temporal evolution for all campaign days. On the same figure, we also show the aerosol number concentrations of nucleation, Aitken and accumulation mode particles ( $30 \mathrm{~nm}$ and $100 \mathrm{~nm}$ are used as the cut-off values of the diameters between the modes). It is possible to identify three types of periods that are connected to the weather conditions: (1) clean conditions with very low concentrations of particles, usually associated with periods after rain; (2) periods with a small increase in the total concentration and rapid variations of the concentrations; and (3) periods when new particle formation events occur, typically associated with sunny days with higher temperature and lower humidity.

The six-day period from 27 June to 2 July was selected for further analysis because it exemplifies the first situation, "clean conditions". In the days preceding this period, it had rained, and after the rain stopped, the nucleation, Aitken and accumulation mode concentrations presented average values of 176, 443 and $239 \mathrm{~cm}^{-3}$, respectively. Those measures were taken as background values for the ALOMAR station.

The period from 28 July to 1 August corresponds to the second situation described. Very rapid variations in the number concentrations were observed during this period, with the three modes maintaining the high mean values of 1186, 647 and $460 \mathrm{~cm}^{-3}$, respectively.

The observed new particle formation events caused the total particle concentration to increase from several hundred particles $\mathrm{cm}^{-3}$ to over 1000 particles $\mathrm{cm}^{-3}$. The criteria for identifying new particle formation events are based upon observations of the rapid growth of particles from $10 \mathrm{~nm}$ to larger sizes in a relatively short time, forming a bananashaped growth curve in the surface plot. An example of a typical particle formation event measured at ALOMAR took place on 20 July. At 07:00 UTC, newly formed particles with diameters of less than $30 \mathrm{~nm}$ increased in number concentration until the nucleation mode reached $3912 \mathrm{~cm}^{-3}$. After that value had been achieved, the particles grew at a rate of a few $\mathrm{nm} \mathrm{h}^{-1}$, reaching sizes of between 30 and $100 \mathrm{~nm}$ by evening and sizes larger than $100 \mathrm{~nm}$ by nightfall. The Aitken mode reached a maximum of $2580 \mathrm{~cm}^{-3}$ at 17:00 UTC, and the accumulation mode reached a maximum of $928 \mathrm{~cm}^{-3}$ at 01:00 UTC on 21 July.

In Fig. 1, the trajectory arriving from sector 4 (day $3 \mathrm{Au}-$ gust - red line) is presented as an example of the most common air mass associated with the occurrence of new particle formation events. Thirteen cases were identified as potential new particle formation events; $54 \%, 23 \%$ and $15 \%$ of those events corresponded to air masses arriving from sector $4(\mathrm{NNE})$, sector $6(\mathrm{~W})$ and sector $5(\mathrm{NW})$, respectively. These results are in agreement with the results published by Kulmala et al. (2005) for the Hyytiälä station and with those of Maso et al. (2007) for four Nordic stations (Hyytiälä, Aspvreten, Värriö and Pallas), which established the Arctic and North Atlantic areas as the sources of air masses leading to new particle formation. The trajectories arriving from sectors 5 (yellow line) and 6 (green line) refer to the days 15 August and 25 July, respectively. The trajectory presented for sector 5 is also an example of a new particle formation event day. The air masses arriving from sectors 4 and 5 are similar in the values registered for the optical and the microphysical parameters of the particles. The air masses arriving from sector 6 present higher concentration of particles and with higher optical parameters than those arriving from sectors 4 and 5 .

The median size distribution for all campaign days is presented in Fig. 4, showing the median, 16th and 84th percentiles of each measured size section. The thicker line indicates the median size distribution collected for all campaign days, and the colored lines indicate the size distribution associated with each of the 6 sectors considered. A bimodal shape is observed for the submicrometer fraction. The Aitken mode, which is rather flat for diameters from 40 to $50 \mathrm{~nm}$, has a maximum concentration of $627 \mathrm{~cm}^{-3}$. The accumulation mode occurs for diameters from 140 to $170 \mathrm{~nm}$ and has a maximum concentration of $260 \mathrm{~cm}^{-3}$. The APS data show a small mode at $2300 \mathrm{~nm}$ for the coarse fraction, Fig. 4b. Sector 2 (SE) presents the most distinct shape and has the highest concentration of particles, with a peak near $100 \mathrm{~nm}$. Sectors 1 and 3 ( $\mathrm{S}$ and $\mathrm{E}$ ), present similar shapes, but higher concentrations are observed for sector 1 . The submicrometer fractions for these three air masses are distributed monomodally. The submicrometer fractions for sectors 4, 5 and 6 (NNE, NW and $\mathrm{W}$ ) present a bimodal shape; higher concentrations are observed for sector 6 , and lower concentrations are observed for sector 5 .

During all the field campaign, the nucleation mode occurred more often in sectors 1 and 6 (S and $\mathrm{W}$ ), whereas the Aitken and accumulation modes presented the highest concentrations in sectors 1, 2 and 3 (S, SE and E). The micrometer fraction was present at very low concentrations in all sectors, with the highest concentration in sector 2 (SE) and the lowest concentration in sector $5(\mathrm{NW})$. Particles in the total size range, from 3 to $10000 \mathrm{~nm}$, were present in sectors 1 and 

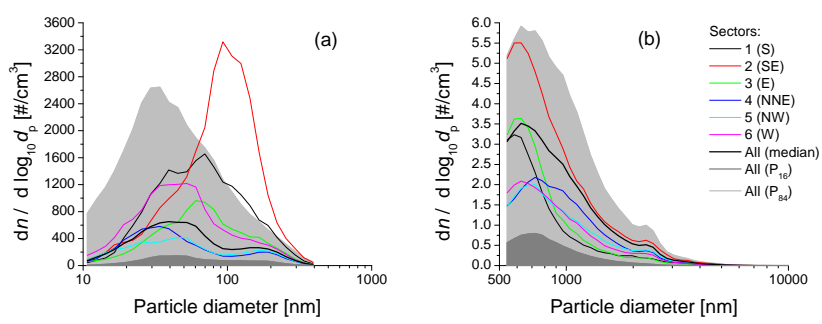

Fig. 4. Median size distributions (thicker black line) and 16th and 84th percentile distributions (shaded areas) for the: (a) submicrometer particles, (b) micrometer particles. The colored lines represent the median size distributions observed in different air masses.

2 (S and SE) at higher concentrations; sector 3 (E) presented lower concentrations, see Fig. 8c.

The relationship between the Aitken and accumulation modes, $N_{30-100} / N_{100}$, was investigated by examining the concentration of particles with sizes between 30 and $100 \mathrm{~nm}$ as a function of $N_{100}$ concentrations (a scatter plot of $N_{30-100}$ versus $N_{100}$ is available as Supplement accompanying this paper, Supplement). The $N$ values are concentrated mainly in a grouping between 100 and $1000 \mathrm{~cm}^{-3}$, and the $N_{30-100} / N_{100}$ ratio remained mostly above 1 throughout the campaign (range: 0.15 to 161.52 ; average: 4.47 ; StD: 7.67).

Based on the bimodal shape of the median size distribution, on the particle concentrations for each size range and on the shape of the area with the greatest density of points in the $N_{30-100}$ versus $N_{100}$ scatter plot, we conclude that the ALOMAR station is sufficiently similar to other Nordic stations and can be included in the group "Northern European Aerosol". This classification was presented by Asmi et al. (2011) (including the stations of Birkenes, Vavihill, Aspvreten, Hyytialä and Pallas), which refers to stations that are sufficiently similar, with regard to these parameters, to be described as the same type dominated by clean continental and Atlantic aerosols but with the occasional influence of more polluted air masses.

\subsection{Relationships between the aerosol parameters}

In Fig. 5a, c, we present the correlation between scattering/absorption in the various channels. The relation between channels describes the proportion of the measurements at different wavelengths, and each pair of measurements should obey Eq. (1). In this way, the slope of the linear fit for each correlation between the channels is the respective Ångström exponent. For the absorption coefficients, one line is sufficient to correlate the different channels, but two lines with different slopes are observed for the scattering coefficients. Since the slopes of the lines depend on the particle size, those two lines appear to represent different aerosol types, and the Ångström exponent can be used to help identify the aerosol types, that can be the result of transport from differ-
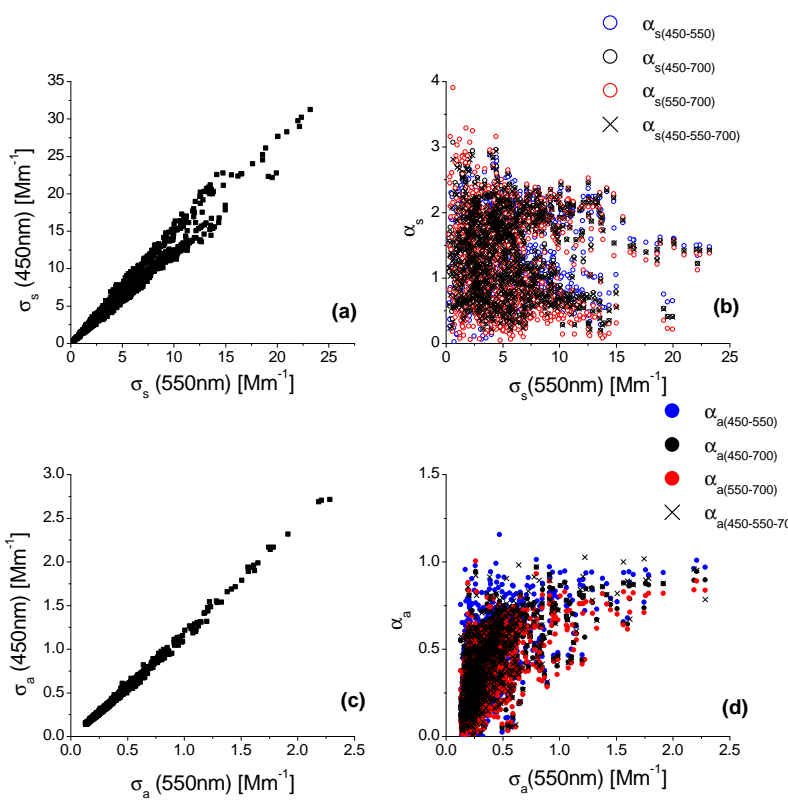

- $\alpha_{\mathrm{a}(450-550)}$

- $\alpha_{\mathrm{a}(450-700)}$
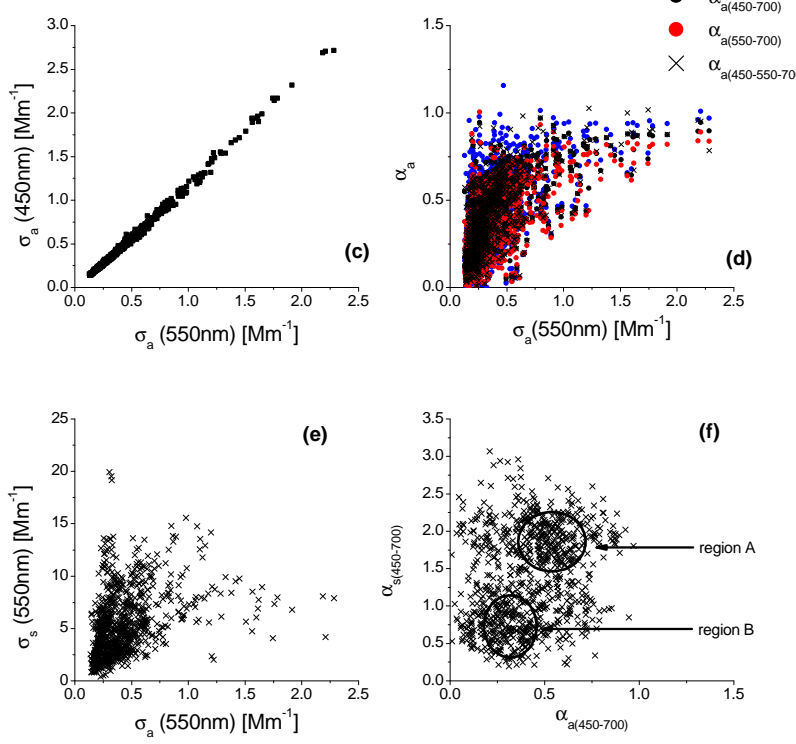

Fig. 5. (a, c) Hourly average values of the scattering and absorption for different wavelengths. (b, d) Hourly average values of the $\sigma_{\mathrm{s}}$ and $\sigma_{\mathrm{a}}$ as a function of the respective Ångström exponents. Relationship between the coefficients $\sigma_{\mathrm{s}}$ and $\sigma_{\mathrm{a}}(\mathbf{e})$ and between the slopes $\alpha_{\mathrm{s}}$ and $\alpha_{\mathrm{a}}(\mathbf{f})$.

ent regions. The line with smaller slope is associated with larger particles, most likely marine aerosols (also dust particles during desert events). The data that contribute to this line have a strong correlation with the number concentrations of the coarse particles $N_{\text {micrometer }}(>500 \mathrm{~nm})$ as demonstrated by the value $R=0.9$. The line with the higher slope is associated with smaller particles, i.e., continental or polluted aerosols, and its data present a correlation of $R=0.6$ with the concentration of particles in the accumulation mode, $N_{100}$.

Additionally, in Fig. 5b, d, we present the relation between the scattering/absorption coefficients and the respective Ångström exponents. The Ångström exponents were calculated for the pairs of wavelengths $450 \mathrm{~nm} / 550 \mathrm{~nm}\left(\alpha_{\mathrm{a}, \mathrm{s}}(450-550)\right), 550 \mathrm{~nm} / 700 \mathrm{~nm}\left(\alpha_{\mathrm{a}, \mathrm{s}}(550-\right.$ $700))$ and $450 \mathrm{~nm} / 700 \mathrm{~nm}\left(\alpha_{\mathrm{a}, \mathrm{s}}(450-700)\right)$, and for the three wavelengths $450 \mathrm{~nm} / 550 \mathrm{~nm} / 700 \mathrm{~nm}\left(\alpha_{\mathrm{a}, \mathrm{s}}(450-550\right.$ 700)). For both scattering and absorption cases, the 
Ångström exponents are higher for the pair of wavelengths $450 \mathrm{~nm} / 550 \mathrm{~nm}$ and smaller for the pair $550 \mathrm{~nm} / 700 \mathrm{~nm}$, thereby defining the shape of the scattering and absorption spectra in the following way: decreases quickly in the $450 \mathrm{~nm} / 550 \mathrm{~nm}$ range and decreases less abruptly in the $550 \mathrm{~nm} / 700 \mathrm{~nm}$ range. Thus, both coefficients are more sensitive to spectral variations at low wavelengths than at high wavelengths of the visible spectrum. For the Ångström exponents, we determined the fit error, $e$, and the quality of the fit using the $R$ parameter. The fit error was calculated as the standard error of the slope of the best-fit line for the observed data $\sigma \times \lambda$ - its mean value is $23 \%$. The $R$ parameter was computed as the fraction of the total variation of the $\sigma$ values of data points that are attributable to the assumed fitting line and was only used qualitatively to evaluate the fit. Both $e$ and $R$ were used to evaluate and filter the data set.

Figure 5e illustrates the relationship between the scattering and absorption coefficients. This represents another way to analyze the single-scattering albedo parameter, and the low values of $\sigma_{\mathrm{a}}$ compared to those of $\sigma_{\mathrm{s}}$ are responsible for the high $\omega_{0}$ values observed. In Fig. 5f, the relationship between the Ångström exponents is also presented, and two regions can be identified as exhibiting a higher density of data. Region A, with higher $\alpha_{\mathrm{a}}$ and $\alpha_{\mathrm{s}}$ values, indicates light absorption by smaller particles, and region $\mathrm{B}$, with lower $\alpha_{\mathrm{a}}$ and $\alpha_{\mathrm{s}}$ values, indicates light absorption by larger particles. These two regions represent the two modes that were observed in the frequency histogram of the $\alpha_{\mathrm{s}}$ parameter (Fig. 3d). In Fig. 3d, the higher density near $\alpha_{\mathrm{s}}=0.7$ and $\alpha_{\mathrm{s}}=1.9$ and the lower density near $\alpha_{\mathrm{s}}=1.3$ should be noted. The $\alpha_{\mathrm{S}}$ values can be explained by the aerosol size distributions measured by the APS, as the count mean diameter of the size distribution (see Fig. 7c and its explanation in the text) presents a correlation of -0.70 , with smaller particles associated with higher $\alpha_{\mathrm{s}}$ values. Because $\alpha_{\mathrm{a}}$ depends on the chemical composition of the particles (as mentioned before, different aerosol species present different $\lambda$ dependencies on light absorption), we conclude that region A, which has higher exponents due to the presence of smaller particles, presents the characteristics of continental polluted aerosols, which may originate from continental urban sources. Region B, which has lower exponents due to the presence of coarse particles, which are clean and less absorbent, may be of marine origin. This conclusion is further supported by the frequency of occurrence of the trajectories for each region. $75 \%$ of the data contributing for region $\mathrm{A}$ arrived from sectors 1,2 and 3 and $95 \%$ of the data contributing for region B arrived from sectors 4,5 and 6.

Figure 6 displays the value of $\omega_{0}$ as a function of the scattering/absorption coefficients and the Ångström exponents. A comparison of $\omega_{0}$ with $\sigma_{\mathrm{a}}$ and $\sigma_{\mathrm{s}}$ was performed in order to identify the darkest and the whitest aerosols. The data are classified according to $\sigma_{\mathrm{a}}$ into three groups, namely $<0.23 \mathrm{Mm}^{-1}, 0.23-0.48 \mathrm{Mm}^{-1}$ and $>0.23 \mathrm{Mm}^{-1}$ (corresponding to the first quartile, second + third quartiles and
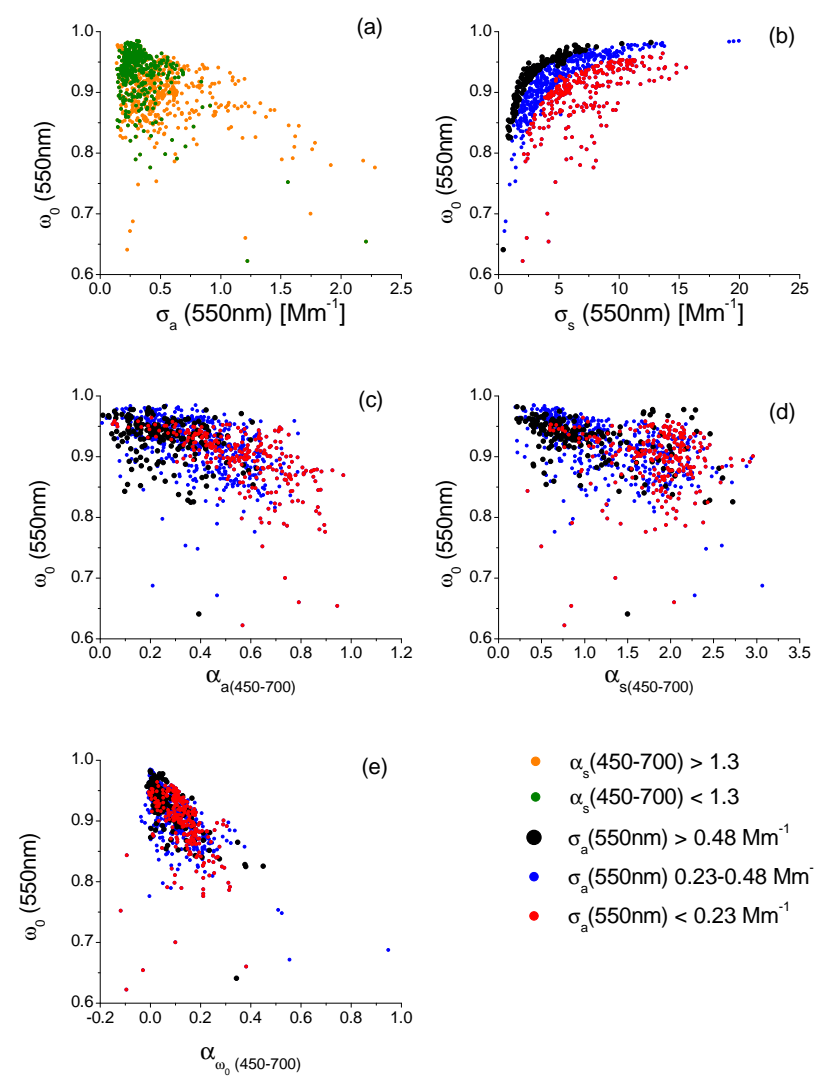

$\begin{array}{ll}- & \alpha_{s}(450-700)>1.3 \\ \text { - } & \alpha_{s}(450-700)<1.3 \\ \text { - } & \sigma_{\mathrm{a}}(550 \mathrm{~nm})>0.48 \mathrm{Mm}^{-1} \\ \text { - } & \sigma_{\mathrm{a}}(550 \mathrm{~nm}) 0.23-0.48 \mathrm{Mm}^{-1} \\ \text { - } & \sigma_{\mathrm{a}}(550 \mathrm{~nm})<0.23 \mathrm{Mm}^{-1}\end{array}$

Fig. 6. Hourly average values of the single scattering albedo as a function of the (a) absorption coefficient, (b) scattering coefficient, (c) absorption Ångström exponent, (d) scattering Ångström exponent and (e) exponent $\alpha_{\omega_{0}}$.

fourth quartile, respectively). Any absorption value may lead to the lowest values of $\omega_{0}$, whereas for scattering, the lowest $\omega_{0}$ values are observed in the lowest $\sigma_{\mathrm{s}}$ range $\left(<5 \mathrm{Mm}^{-1}\right)$. A comparison between $\omega_{0}$ and $\alpha_{\mathrm{a}}$ is also of interest, since the wavelength dependency of the absorption is related to the composition of the aerosols. This is shown in Fig. 6c. The most absorbent particles exhibit $\alpha_{\mathrm{a}}$ values below 0.6, while the less absorbent particles present higher $\alpha_{\mathrm{a}}$ values, reaching near unity. In Fig. 6d, $\omega_{0}$ is compared to $\alpha_{\mathrm{s}}$ to search for information on the size of the aerosols and to examine whether the optical data can provide support for the size distribution measurements. The joint analysis of Fig. 6a and Fig. 6c shows that, for a given $\sigma_{\mathrm{a}}$ value, lower $\omega_{0}$ values correspond to higher $\alpha_{\mathrm{s}}$ values, and higher $\omega_{0}$ values correspond to smaller $\alpha_{\mathrm{s}}$ values. This result agrees with that obtained by Clarke et al. (2007) and, considering that $\alpha_{\mathrm{s}}$ is higher for smaller particles (see Fig. 7c and its explanation in the text), one can conclude that, for a given $\sigma_{\mathrm{a}}$ value, lower $\omega_{0}$ values correspond to smaller particles, and higher $\omega_{0}$ values correspond to larger particles. In Fig. 6e, the single-scattering albedo, $\omega_{0}$, is plotted against its own exponent, $\alpha_{\omega_{0}}$. The spectral shape decreases mainly with the 


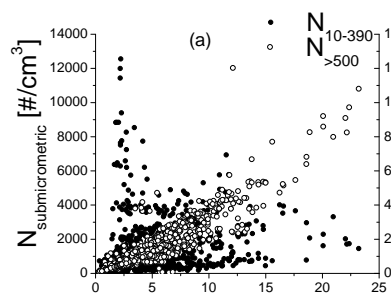

$\sigma_{\mathrm{s}}\left[\mathrm{Mm}^{-1}\right]$
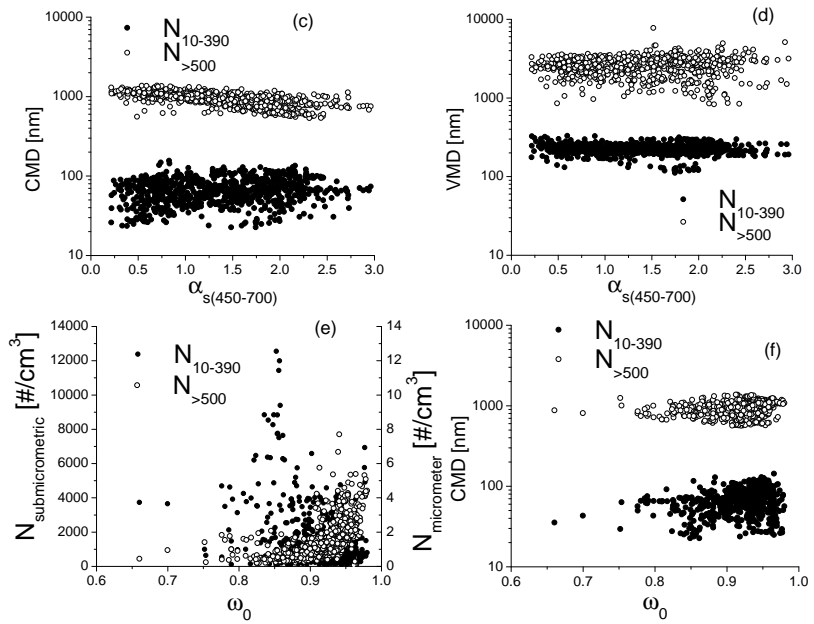

Fig. 7. Relation between $\sigma_{\mathrm{s}}$ and (a) micrometer and submicrometer concentrations, (b) nucleation, Aitken and accumulation modes. (c) Relation between the size of the particles (CMD) and $\alpha_{\mathrm{s}}$. (d) Relation between the size of the particles (VMD) and $\alpha_{\mathrm{s}}$. (e) Relation between $\omega_{0}$ and the micrometer and submicrometer concentrations. (f) Particle size (CMD) as a function of $\omega_{0}$.

wavelength, $\alpha_{\omega_{0}}>0$, but in some cases the single scattering albedo increases with the wavelength $\left(\alpha_{\omega_{0}}<0\right)$. This situation has been reported in previous studies to be a result of the arrival of dust (Rodríguez et al., 2011). Only a few such occurrences (very weak) took place during our measurements, and these cases were characterized by higher total particle number concentrations, such as $3919 \mathrm{~cm}^{-3}$.

According to Cappa et al. (2009), the relationship between $\omega_{0}$, an intensive aerosol optical property, and $\sigma_{\mathrm{a}}$, an extensive property, can be used to differentiate between background aerosols and the inputs of primary aerosols. Applying this methodology at the ALOMAR station, we observe predominantly high values of $\omega_{0}$ caused by very low $\sigma_{\mathrm{a}}$ values. This fact, together with the $\alpha_{\mathrm{s}}$ values registered, allows us to describe the local air as extremely clean and only episodically influenced by small particles resulting from long-range transport. This conclusion is also supported by results obtained by other techniques, such as the analysis of the air mass origins (see Sect. 3.4) and the use of MODIS images and columnar data from the CIMEL photometer (shown in Rodríguez et al., 2011).

Figure $7 \mathrm{a}, \mathrm{b}$ illustrates the particle number concentration in different size fractions and modes as a function of the scat-
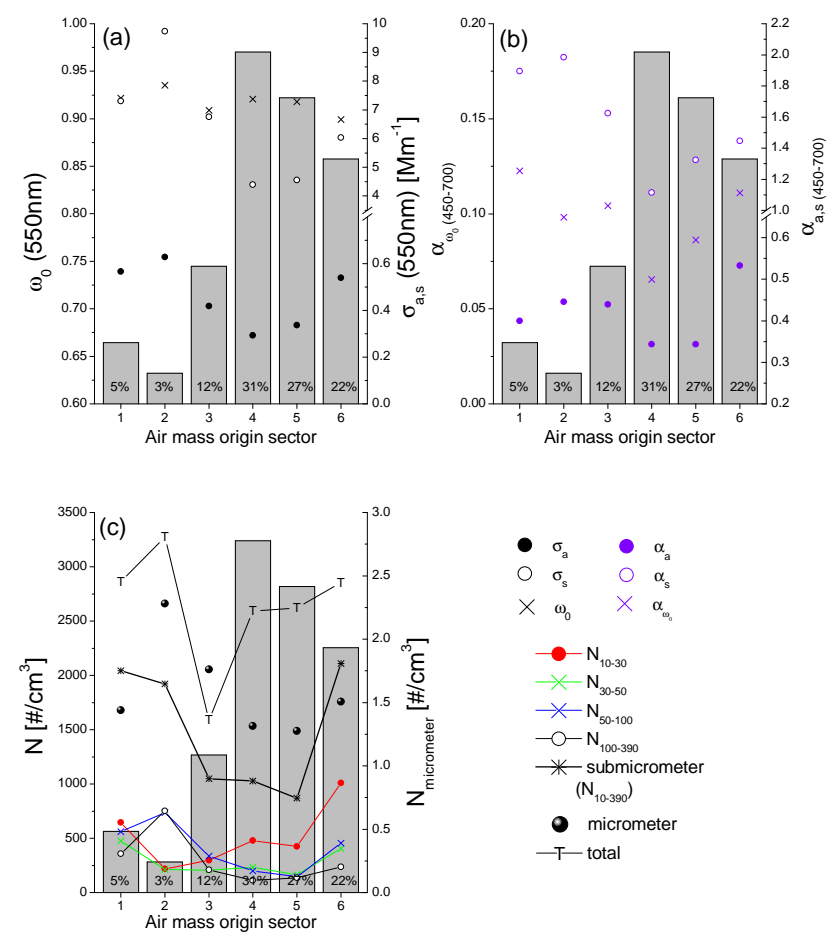

Fig. 8. Classification of air masses according to their origin. Percentage values refer the frequency of each air mass origin. $(\mathbf{a}, \mathbf{b})$ Summarizes the main characteristics of the optical properties of the aerosols for the six air-mass types. The mean values of $\sigma_{\mathrm{a}}, \sigma_{\mathrm{s}}$ and $\omega_{0}$ for $550 \mathrm{~nm}$ and $\alpha_{\mathrm{a}}, \alpha_{\mathrm{s}}$ and $\alpha_{\omega_{0}}$ for the pair of wavelengths 450 $700 \mathrm{~nm}$ are shown for each sector. (c) Number concentrations observed in each situation.

tering coefficient $(550 \mathrm{~nm})$. Based on the Mie theory, only the supra-micrometer fraction and the accumulation mode are expected to present strong correlations with $\sigma_{\mathrm{s}}$, whereas the scattering coefficient is expected to be unresponsive to the nucleation and Aitken modes. In our results, no clear connection between the total particle number concentration and the scattering coefficient can be seen. However, if we look at specific size ranges, we see that aerosol particle concentration in the coarse mode is strongly correlated $(R=0.9)$ with the scattering coefficient. This correlation is lower for the number concentration of accumulation mode particles $(R=0.5)$. No correlation can be seen for the Aitken and nucleation modes. These results are consistent with those presented by Aaltonen et al. (2006) at the Pallas station, who reported correlations of 0.71 for the coarse fraction and 0.60 for the accumulation mode. However, care should be taken when directly comparing the accumulation mode results, as Aaltonen et al. (2006) considered the range $95-500 \mathrm{~nm}$, whereas our accumulation mode results refer to the range $100-390 \mathrm{~nm}$. It was also previously shown by Virkkula et al. (1998), using results recorded in Finnish Lapland, that the correlation between the total particle number concentration and $\sigma_{\mathrm{s}}$ is low, 
but the correlation between the number concentration in the accumulation mode and $\sigma_{\mathrm{s}}$ is high.

The relationship between the particle size distributions and the scattering Ångström exponent is presented in Fig. 7c, d. The size of the particles is expressed as the count mean diameter of the size distribution, $\mathrm{CMD}=\frac{\sum\left(d_{\mathrm{p}}\right)_{i} N_{i}}{N}$, the surface mean diameter, $\mathrm{SMD}=\frac{\sum\left(d_{\mathrm{p}}\right)_{i} S_{i}}{S}$ (not shown) and the volume mean diameter, VMD $=\frac{\sum\left(d_{\mathrm{p}}\right)_{i} V_{i}}{V}$. For the submicrometer fraction, the value of $\alpha_{\mathrm{s}}$ is insensitive to the size distribution. The correlation coefficients are $0.19,-0.04$ and -0.06 for CMD, SMD and VMD, respectively. For the micrometer fraction, the value of $\alpha_{\mathrm{s}}$ is correlated most strongly with the CMD. The fits are $-0.70,-0.12$ and 0.10 for CMD, SMD and VMD, respectively. In the studies by Virkkula et al. (1998) and Garland et al. (2008), it was observed that the correlation of CMD with $\alpha_{\mathrm{s}}$ is not as strong as the correlation of SMD and VMD with $\alpha_{\mathrm{s}}$. This difference occurs because the size distribution was considered as a whole in both works cited. However, in our work, the analysis is performed separately for the submicrometer and micrometer fractions. Consideration of all sizes biases the correlation with CMD because it gives more weight to the small particles, which are less sensitive to scattering.

The fraction of particles that contribute to each $\omega_{0}$ value is shown in Fig. 7e, and Fig. $7 f$ presents the size of the particles as a function of $\omega_{0}$. In practice, Fig. 7e has the same meaning as Fig. 6a, b, as confirmed by the similar shape of the graphs. Note the similar shape between the graphs of $\omega_{0} \times \sigma_{\mathrm{a}}$ and $N_{\text {submicrometer }} \times \omega_{0}$, confirming that for a given value of $\sigma_{\mathrm{a}}$, lower values of $\omega_{0}$ correspond to smaller particles and higher values of $\omega_{0}$ correspond to larger particles. Likewise, the graphs of $\omega_{0} \times \sigma_{\mathrm{a}}$ and $N_{\text {micrometer }} \times \omega_{0}$ also present similar shapes. In Fig. 7f, we see that for the submicrometer fraction, the CMD varied from $\sim 20$ to $\sim 160 \mathrm{~nm}$, with an average value of $66 \mathrm{~nm}$. For the micrometer fraction, the CMD varied from $\sim 500$ to $\sim 1400 \mathrm{~nm}$, with an average value of $900 \mathrm{~nm}$. Classifying the $\omega_{0}$ in 5 bins, $\omega_{0}<0.80,0.80-0.85$, $0.85-0.90,0.90-0.95$ and $0.95-1.00$, we observe that the average values of the CMD for the submicrometer and the micrometer fractions occurred in the bins $0.80-0.85$ and $0.85-$ 0.90 , respectively. The smallest average CMD, $57 \mathrm{~nm}$, typical of new particle formation episodes, was calculated in the bin $\omega_{0}>0.95$. This value is slightly higher than that presented by Virkkula et al. (2011) at the Hyytiälä station, located in Southwestern Central Finland. The highest average CMD, $1065 \mathrm{~nm}$, which was typical of long-range pollution episodes, was also calculated in the bin $\omega_{0}>0.95$.

\subsection{Transport pathways of the air masses arriving at ALOMAR}

In addition to the special cases presented previously, the air mass trajectories and optical and microphysical data were statistically analyzed. Sectors 1, 2 and 3 (S, SE and E) an- alyzed as a whole yield higher $\sigma_{\mathrm{a}}$ and $\sigma_{\mathrm{s}}$ coefficients and higher $\alpha_{\mathrm{a}}$ and $\alpha_{\mathrm{s}}$ exponents than in sectors 4,5 and $6\left(\sigma_{\mathrm{a}}\right.$, $\sigma_{\mathrm{s}}, \alpha_{\mathrm{a}}$ and $\alpha_{\mathrm{s}}$ are $27 \%, 37 \%, 5 \%$ and $29 \%$ higher, respectively, for sectors 1, 2 and 3 than for sectors 4, 5 and 6). On average, these sectors are described by a monomodal size distribution and contain far more accumulation mode particles and higher number concentrations than sectors 4, 5 and 6. This situation, as with the continental air, corresponds to region A, which is shown in Fig. 5f. Sector 2 presents the strongest accumulation mode, with a count of $3319 \mathrm{~cm}^{-3}$ for particles close to $100 \mathrm{~nm}$ in diameter, but the air masses arriving from this sector represent only $3 \%$ of occurrences. Sectors 1 and 3 present maximum concentrations of $1656 \mathrm{~cm}^{-3}$ and $963 \mathrm{~cm}^{-3}$, respectively, at particles with sizes of $70 \mathrm{~nm}$ and $60 \mathrm{~nm}$.

Sectors 4, 5 and 6 (NNE, NW and W), also analyzed as a whole, present lower coefficients and lower exponents, corresponding to region B in Fig. 5f, for marine air. The size distribution of the submicrometer fraction for sectors 4,5 and 6 is markedly bimodal, and the number concentrations are lower than in sectors 1,2 and 3. The lowest scattering and absorption coefficients were observed for sector 4 , and the lowest particle concentration was observed for sector 5 . A more detailed discussion, in which each sector could be further broken up into special regions and in which the characteristics of mixed air masses could be specified, would require data from longer measurement periods.

\section{Summary and conclusions}

Aerosol optical and microphysical properties were investigated during the summer of 2008 at the ALOMAR station, located in Andøya island on the Atlantic coast of Norway, approximately $300 \mathrm{~km}$ north of the Arctic Circle. Basic statistical values for all data were presented, as were intra-data relationships and particle size distributions. Finally source regions were analyzed both by presenting specific events and by applying a trajectory statistical method.

The primary optical measurements made were light absorption by particle soot absorption photometry and light scattering by nephelometry. The scattering coefficients were strongly variable, ranging from 0.25 to $23.21 \mathrm{Mm}^{-1}$ at $550 \mathrm{~nm}$, whereas the absorption coefficients, also at $550 \mathrm{~nm}$, were more consistent, ranging from 0.13 to $2.28 \mathrm{Mm}^{-1}$. The mean absorption coefficient was very small, leading to high single-scattering albedos (mean $\omega_{0}=0.91$, range 0.62 0.99 at $550 \mathrm{~nm}$ ). The scattering and absorption Ångström exponents showed similar behavior, with higher values from 450 to $550 \mathrm{~nm}$ and smaller values from 550 to $700 \mathrm{~nm}$. The spectral dependence of the single scattering albedo was also analyzed and it mainly decreases with wavelength. However, some cases were noted in which the single scattering albedo increases with the wavelength. We analyzed the main characteristics of the microphysical properties of aerosols by determining the number size distributions and its parameters 
provided by the SMPS, APS and UCPC and by examining the aerosol evolution during the campaign. The observed mean total number concentration was $2463 \mathrm{~cm}^{-3}$. The median number size distributions were obtained and compared with those from other Northern European locations. The submicrometer fraction of the aerosol particles exhibited a bimodal number size distribution. The Aitken mode presented a maximum concentration of $627 \mathrm{~cm}^{-3}$, and the accumulation mode presented a maximum concentration of $260 \mathrm{~cm}^{-3}$. The ratio between the Aitken and the accumulation modes remained mostly above 1 , which is typical of northern European locations. These results can be regarded as typical of those obtained in summer in this region, and the low values of the optical and microphysical parameters indicate that the predominant regional aerosols are mostly clean.

In practice, the scattering and absorption Ångström exponents are often used as qualitative indicators of particle size and chemical composition, respectively. At the ALOMAR station, one line proved to be sufficient to correlate the different channels of absorption coefficients, meaning that only one type of absorbent particle is usually present. In contrast, two lines with different slopes are necessary to accurately correlate different channels of scattering coefficients, representing two aerosol sizes. The line with the smaller slope (smaller $\alpha_{\mathrm{s}}$ ) is associated with larger particles, as demonstrated by the strong correlation with the number concentrations of coarse particles $(R=0.9)$, and the line with the higher slope (higher $\alpha_{\mathrm{s}}$ ) is associated with fine particles $(R=0.6)$. To further explore the relationship between the wavelength dependence of the scattering coefficient and the size of the particles, $\alpha_{\mathrm{s}}$ was compared with the submicrometer and micrometer size distributions in terms of count mean diameters, surface mean diameters and volume mean diameters. Only the micrometer CMD proved to be correlated with $\alpha_{\mathrm{s}}$, which occurred because particles smaller than $100 \mathrm{~nm}$ provide only a small contribution to the scattering $\left(\sigma_{\mathrm{s}}\right.$ correlated strongly with the number concentration of accumulation mode particles and more strongly with the micrometer fraction of particles, but poor correlations were obtained for the Aitken and nucleation modes). However, the $\alpha_{\mathrm{s}}$ parameter can still be used as an indicator of particle size if our aim is only to distinguish between the accumulation mode and the coarse mode.

A back trajectory analysis showed significant differences in the optical parameters between the maritime air masses (NNE, NW and W) and continental air masses (S, SE and E). The cleanest conditions were observed in connection with air masses arriving from the Arctic Ocean and the North Atlantic (NNE, NW), which were associated with the lowest optical and microphysical parameters and the lowest particle number concentrations. These air masses contained predominantly non-absorbent, coarser particles, and the size distribution is markedly bimodal. New particle formation events take place more often under these conditions (mainly in air masses with a NNE origin). The most contaminated condi- tions were observed in connection with air masses arriving from Great Britain, Scandinavia, eastern Europe and Russia ( $\mathrm{S}, \mathrm{SE}$ and $\mathrm{E}$ ), in which continental aerosols were predominant and presented higher values for all optical parameters. This result indicates the presence of smaller absorbent particles and explains the smaller values recorded for $\omega_{0}$. The size distribution is monomodal and contains more accumulation mode particles and higher number concentrations than the air masses arriving from NNE, NW and W.

Most of the parameters measured at and calculated for this site are similar to those of other northern areas. Interest in these data relies on the previously unavailable variety of information for this area, which allowed us to accomplish our aim and determine the general characteristics of local aerosols for the first time. Finally, we would like to point out that this study, which was conducted using a small data set representing measurements recorded over nearly three months, allowed us to clearly distinguish between two aerosol types characteristic of well established situations. The same work, if conducted over a larger (preferably year-long) data set, would allow for more situations to be distinguished, in ALOMAR and other measurement sites.

\section{Supplementary material related to this article is available online at: http://www.atmos-chem-phys.net/12/ 5841/2012/acp-12-5841-2012-supplement.pdf.}

Acknowledgements. We thank ALOMAR team for their help and dedication and the INTA team for providing and operating part of the instrumentation. We thank the Division of Atmospheric Sciences (Helsinky University) team headed by M. Kulmala, and L. Laakso, for calibration facilities. Also, we thank the POLARCAT staff.

Financial support from the Spanish CICYT CGL2009-322 09740 and Complementary Action CGL2010-09480-E are gratefully acknowledged.

The authors gratefully acknowledge the NOAA Air Resources Laboratory (ARL) for provision of the HYSPLIT transport and dispersion model and the READY website used in this publication (www.arl.noaa.gov/ready.html).

This work is dedicated by S. Mogo to Judite Fitas, a beautiful woman who has taught me how to spread my wings and fly. You made me who I am today and I thank you for every moment you share with me.

Edited by: A. Stohl 


\section{References}

Aaltonen, V., Lihavainen, H., Kerminen, V.-M., Komppula, M., Hatakka, J., Eneroth, K., Kulmala, M., and Viisanen, Y.: Measurements of optical properties of atmospheric aerosols in Northern Finland, Atmos. Chem. Phys., 6, 1155-1164, doi:10.5194/acp-6-1155-2006, 2006.

Aamaas, B., Bøggild, C., Stordal, F., Berntsen, T., Holmén, K., and Ström, J.: Elemental carbon deposition to Svalbard snow from Norwegian settlements and long-range transport, Tellus, 63B, 340-351, 2011.

Anderson, T. and Ogren, J.: Determining aerosol radiative properties using the TSI 3563 integrating nephelometer, Aerosol Sci. Technol., 29, 57-69, 1998.

Anderson, T., Covert, D., Marshall, S., Laucks, M., Charlson, R., Waggoner, A., Ogren, J., Caldow, R., Holm, R., Quant, F., Sem, G., Wiedensohler, A., Ahlquist, N., and Bates, T.: Performance characteristics of a high-sensitivity, three-wavelength, total scatter/backscatter nephelometer, J. Atmos. Ocean. Technol., 13, 967-986, 1996.

Asmi, A., Wiedensohler, A., Laj, P., Fjaeraa, A.-M., Sellegri, K., Birmili, W., Weingartner, E., Baltensperger, U., Zdimal, V., Zikova, N., Putaud, J.-P., Marinoni, A., Tunved, P., Hansson, H.C., Fiebig, M., Kivekäs, N., Lihavainen, H., Asmi, E., Ulevicius, V., Aalto, P. P., Swietlicki, E., Kristensson, A., Mihalopoulos, N., Kalivitis, N., Kalapov, I., Kiss, G., de Leeuw, G., Henzing, B., Harrison, R. M., Beddows, D., O’Dowd, C., Jennings, S. G., Flentje, H., Weinhold, K., Meinhardt, F., Ries, L., and Kulmala, M.: Number size distributions and seasonality of submicron particles in Europe 2008-2009, Atmos. Chem. Phys., 11, 5505-5538, doi:10.5194/acp-11-5505-2011, 2011.

Birmili, W., Wiedensohler, A., Heintzenberg, J., and Lehmann, K.: Atmospheric particle number size distribution in central Europe: Statistical relations to air masses and meteorology, J. Geophys. Res., 106, 32005-32018, 2001.

Bond, T.: Spectral dependence of visible light absorption by carbonaceous particles emitted from coal combustion, Geophys. Res. Lett., 28, 4075-4078, 2001.

Bond, T., Anderson, T., and Campbell, D.: Calibration and intercomparison of filter-based measurements of visible light absorption by aerosols, Aerosol Sci. Technol., 30, 582-600, 1999.

Boucher, O. and Haywood, J.: On summing the components of radiative forcing of climate change, Clim. Dynam., 18, 297-302, 2001.

Cappa, C., Bates, T., Quinn, P., and Lack, D.: Source characterization from ambient measurements of aerosol optical properties, Geophys. Res. Lett., 36, L14813, doi:10.1029/2009GL038979, 2009.

Clarke, A. and Noone, J.: Measurements of soot aerosol in Arctic snow, Atmos. Environ., 19, 2045-2054, 1985.

Clarke, A., McNaughton, C., Kapustin, V., Shinozuka, Y., Howell, S., Dibb, J., Zhou, J., Anderson, B., Brekhovskikh, V., Turner, H., and Pinkerton, M.: Biomass burning and pollution aerosol over North America: Organic components and their influence on spectral optical properties and humidification response, J. Geophys. Res., 112, D12S18, doi:10.1029/2006JD007777, 2007.

Collaud Coen, M., Weingartner, E., Schaub, D., Hueglin, C., Corrigan, C., Henning, S., Schwikowski, M., and Baltensperger, U.: Saharan dust events at the Jungfraujoch: detection by wavelength dependence of the single scattering albedo and first climatology analysis, Atmos. Chem. Phys., 4, 2465-2480, doi:10.5194/acp4-2465-2004, 2004.

Delene, D. and Ogren, J.: Variability of aerosol optical properties at four North American surface monitoring sites, J. Aerosol Sci., 59, 1135-1150, 2002.

Doherty, S. J., Warren, S. G., Grenfell, T. C., Clarke, A. D., and Brandt, R. E.: Light-absorbing impurities in Arctic snow, Atmos. Chem. Phys., 10, 11647-11680, doi:10.5194/acp-1011647-2010, 2010.

Draxler, R. and Rolph, G.: (HYbrid Single-Particle Lagrangian Integrated Trajectory) Model access via NOAA ARL READY Website (http://www.arl.noaa.gov/ready/hysplit4.html), NOAA Air Resources Laboratory, Silver Spring, MD, 2003.

Dubovik, O., Holben, B., Eck, T., Smirnov, A., Kaufman, Y., King, M., Tanré, D., and Slutsker, I.: Variability of absorption and optical properties of key aerosol types observed in worldwide locations, J. Atmos. Sci., 59, 590-608, 2002.

Forsström, S., Ström, J., Pedersen, C., Isaksson, E., and Gerland, S.: Elemental carbon distribution in Svalbard snow, J. Geophys. Res., 114, D19112, doi:10.1029/2008JD011480, 2009.

Garland, R. M., Yang, H., Schmid, O., Rose, D., Nowak, A., Achtert, P., Wiedensohler, A., Takegawa, N., Kita, K., Miyazaki, Y., Kondo, Y., Hu, M., Shao, M., Zeng, L. M., Zhang, Y. H., Andreae, M. O., and Pöschl, U.: Aerosol optical properties in a rural environment near the mega-city Guangzhou, China: implications for regional air pollution, radiative forcing and remote sensing, Atmos. Chem. Phys., 8, 5161-5186, doi:10.5194/acp-85161-2008, 2008.

Hadley, O. and Kirchstetter, T.: Black-carbon reduction of snow albedo, Nature Clim. Change, doi:10.1038/nclimate1433, 2012.

IPCC: Climate Change 2007, Tech. rep., Intergovernamental Panel on Climate Change, 2007.

Kokhanovsky, A.: Aerosol optics: light absorption and scattering by particles in the atmosphere, Springer, Praxis, 2008.

Kulmala, M., Sogacheva, L., Maso, M. D., and Kerminen, V.-M.: Probability of nucleation events and aerosol particle concentration in different air mass types arriving at Hyytiälä, southern Finland, based on back trajectories analysis, Boreal Env. Res., 10, 479-491, 2005.

Law, K. and Stohl, A.: Arctic Air Pollution: Origins and Impacts, Science, 315, 1537-1540, doi:10.1126/science.1137695, 2007.

Leck, C. and Bigg, E.: Source and evolution of the marine aerosol - A new perspective, Geophys. Res. Lett., 32, L19803, doi:10.1029/2005GL023651, 2005.

Lin, C., Baker, M., and Charlson, R.: Absorption coefficient of atmospheric aerosol: a method of measurement, Appl. Opt., 12, 1356-1363, 1973.

Lyamani, H., Olmo, F., and Alados-Arboledas, L.: Light scattering and absorption properties of aerosol particles in the urban environment of Granada, Spain, Atmos. Environ., 42, 2630-2642, 2008.

Maso, M. D., Sogacheva, L., Aalto, P., Riipinen, I., Komppula, M., Tunved, P., Korhonen, L., Suur-Uski, V., Hirsikko, A., Kurtén, T., Kerminen, V.-M., Lihavainen, H., Viisanen, Y., Hansson, H.C., and Kulmala, M.: Aerosol size distribution measurements at four Nordic field stations: identification, analysis and trajectory analysis of new particle formation bursts, Tellus, 59, 350-361, doi:10.1111/j.1600-0889.2007.00267.x, 2007. 
Mogo, S., Cachorro, V., Sorribas, M., de Frutos, A., and Fernández, R.: Measurements of continuous spectra of atmospheric absorption coefficients from UV to NIR via optical method, Geophys. Res. Lett., 32, L13811, doi:10.1029/2005GL022938, 2005.

Montilla, E., Mogo, S., Cachorro, V., and de Frutos, A.: An integrating sphere spectral system to measure continuous spectra of aerosol absorption coefficient, J. Aerosol Sci., 42, 204-212, doi:10.1016/j.jaerosci.2011.01.003, 2011.

Müller, T., Henzing, J. S., de Leeuw, G., Wiedensohler, A., Alastuey, A., Angelov, H., Bizjak, M., Collaud Coen, M., Engström, J. E., Gruening, C., Hillamo, R., Hoffer, A., Imre, K., Ivanow, P., Jennings, G., Sun, J. Y., Kalivitis, N., Karlsson, H., Komppula, M., Laj, P., Li, S.-M., Lunder, C., Marinoni, A., Martins dos Santos, S., Moerman, M., Nowak, A., Ogren, J. A., Petzold, A., Pichon, J. M., Rodriquez, S., Sharma, S., Sheridan, P. J., Teinilä, K., Tuch, T., Viana, M., Virkkula, A., Weingartner, E., Wilhelm, R., and Wang, Y. Q.: Characterization and intercomparison of aerosol absorption photometers: result of two intercomparison workshops, Atmos. Meas. Tech., 4, 245-268, doi:10.5194/amt-4-245-2011, 2011.

Pereira, S. N., Wagner, F., and Silva, A. M.: Seven years of measurements of aerosol scattering properties, near the surface, in the southwestern Iberia Peninsula, Atmos. Chem. Phys., 11, 1729, doi:10.5194/acp-11-17-2011, 2011.

Quinn, P., Miller, T., Bates, T., Ogren, J., Andrews, E., and Shaw, G.: A 3-year record of simultaneously measured aerosol chemical and optical properties at Barrow, Alaska, J. Geophys. Res., 107, 4130, doi:10.1029/2001JD001248, 2002.

Quinn, P., Shaw, G., Andrews, E., Dutton, E., Ruoho-Airola, T., and Gong, S.: Arctic haze: current trends and knowledge gaps, Tellus, 59, 99-114, 2007.

Ramanathan, V., Crutzen, P., Kiehl, J., and Rosenfeld, D.: Aerosols, climate, and the hydrological cycle, Science, 294, 2119-2124, doi:10.1126/science.1064034, 2001.

Ricard, V., Jaffrezo, J.-L., Kerminen, V.-M., Hillamo, R., Sillanpaa, M., Ruellan, S., Liousse, C., and Cachier, H.: Two years of continuous aerosol measurements in northern Finland, J. Geophys. Res., 107, 4129, doi:10.1029/2001JD000952, 2002a.

Ricard, V., Jaffrezo, J.-L., Kerminen, V.-M., Hillamo, R., Teinilä, K., and Maenhaut, W.: Size distributions and modal parameters of aerosol constituents in northern Finland during the European Arctic Aerosol Study, J. Geophys. Res., 107, 4208, doi:10.1029/2001JD001130, 2002b.

Rodríguez, E., Toledano, C., Cachorro, V., de Leeuw, G., Frutos, A. D., Gausa, M., and Holben, B.: Comparison of aerosol optical properties at the sub-arctic stations ALOMAR-Andenes, Abisko and Sodankylä in late spring and summer 2007, Atmos. Res., 107, 20-30, doi:10.1016/j.atmosres.2011.12.003, 2012.

Rodríguez, E., Toledano, C., Cachorro, V., Ortiz, P., Stebel, K., Berjón, A., Blindheim, S., Gausa, M., and de Frutos, A.: Aerosol characterization at the sub-Arctic site Andenes $\left(69^{\circ} \mathrm{N}, 16^{\circ} \mathrm{E}\right)$, by the analysis of columnar optical properties, Q. J. Roy. Meteorol. Soc., 137, 948-958, doi:10.1002/qj.921, 2011.

Rolph, G.: Real-time Environmental Applications and Display sYstem (READY) Website (http://www.arl.noaa.gov/ready/hysplit4. html), NOAA Air Resources Laboratory, Silver Spring, MD, 2003.

Rosen, H., Hansen, D., Gundel, L., and Novakov, T.: Carbonaceous particles in the atmosphere, chap. Identification of the graphitic carbon component of source and ambient particulates by Raman spectroscopy and an optical attenuation technique, 229-232, Lawrence Berkeley Laboratory, 1979.

Russell, P. B., Bergstrom, R. W., Shinozuka, Y., Clarke, A. D., DeCarlo, P. F., Jimenez, J. L., Livingston, J. M., Redemann, J., Dubovik, O., and Strawa, A.: Absorption Angstrom Exponent in AERONET and related data as an indicator of aerosol composition, Atmos. Chem. Phys., 10, 1155-1169, doi:10.5194/acp-101155-2010, 2010.

Skatteboe, R.: ALOMAR: atmospheric science using lidars, radars and ground based instruments, J. Atmos. Terr. Phys., 58, 1823 1826, doi:10.1016/0021-9169(95)00173-5, 1996.

Springston, S. and Sedlacek III, A.: Noise charecteristics of an instrumental particle absorbance technique, Aerosol Sci. Technol., 41, 1110-1116, doi:10.1080/02786820701777457, 2007.

Toledano, C., Cachorro, V., Berjón, A., Sorribas, M., Vergaz, R., de Frutos, A., Antón, M., and Gausa, M.: Aerosol optical depth at ALOMAR Observatory (Andøya, Norway) in summer 2002 and 2003, Tellus, 58B, 218-228, 2006.

Toledano, C., Cachorro, V., de Frutos, A., Torres, B., Sorribas, M., and de la Morena, B.: Air mass classification and analysis of aerosol types at El Arenosillo (Spain), J. Appl. Meteor. Climatol., 48, 962-981, 2009.

Tomasi, C., Vitale, V., Lupi, A., Carmine, C. D., Campanelli, M., Herber, A., Treffeisen, R., Stone, R., Andrews, E., Sharma, S., Radionov, V., von Hoyningen-Huene, W., Stebel, K., Hansen, G., Myhre, C., Aaltonen, C. W. V., Lihavainen, H., Hillamo, A V. R., Ström, J., Toledano, C., Cachorro, V., Ortiz, P., de Frutos, A., Blindheim, S., Frioud, M., Gausa, M., Zielinski, T., Petelski, T., and Yamanouchi, T.: Aerosols in polar regions: A historical overview based on optical depth and in situ observations, J. Geophys. Res., 112, D16205, doi:10.1029/2007JD008432, 2007.

Tunved, P., Nilsson, E., Hansson, H.-C., Ström, J., Kulmala, M., Aalto, P., and Viisanen, Y.: Aerosol characteristics of air masses in northern Europe: Influences of location, transport, sinks, and sources, J. Geophys. Res., 110, D07201, doi:10.1029/2004JD005085, 2005.

Virkkula, A., Hillamo, R., Kerminen, V.-M., and Stohl, A.: The influence of Kola Peninsula, continental European and marine sources on the number concentrations and scattering coefficients of the atmospheric aerosol in Finnish Lapland, Boreal Environ. Res., 2, 317-336, 1998.

Virkkula, A., Ahlquist, N., Covert, D., Arnott, W., Sheridan, P., Quinn, P., and Coffman, D.: Modification, calibration and a field test of an instrument for measuring light absorption by particles, Aerosol Sci. Technol., 39, 68-83, 2005.

Virkkula, A., Backman, J., Aalto, P. P., Hulkkonen, M., Riuttanen, L., Nieminen, T., dal Maso, M., Sogacheva, L., de Leeuw, G., and Kulmala, M.: Seasonal cycle, size dependencies, and source analyses of aerosol optical properties at the SMEAR II measurement station in Hyytiälä, Finland, Atmos. Chem. Phys., 11, 4445-4468, doi:10.5194/acp-11-4445-2011, 2011.

Volckens, J. and Peters, T.: Counting and particle transmission eficiency of the aerodynamic particle sizer, J. Aerosol Sci., 36, 1400-1408, 2005.

Vrekoussis, M., Liakakou, E., Koçak, M., Kubilay, N., Oikonomou, K., Sciare, J., and Mihalopoulos, N.: Seasonal variability of optical properties of aerosols in the Eastern Mediterranean, Atmos. Environ., 39, 7083-7094, doi:10.1016/j.atmosenv.2005.08.011, 
2005.

Wiedensohler, A., Birmili, W., Nowak, A., Sonntag, A., Weinhold, K., Merkel, M., Wehner, B., Tuch, T., Pfeifer, S., Fiebig, M., Fjäraa, A. M., Asmi, E., Sellegri, K., Depuy, R., Venzac, H., Villani, P., Laj, P., Aalto, P., Ogren, J. A., Swietlicki, E., Williams, P., Roldin, P., Quincey, P., Hüglin, C., Fierz-Schmidhauser, R., Gysel, M., Weingartner, E., Riccobono, F., Santos, S., Grüning, C., Faloon, K., Beddows, D., Harrison, R., Monahan, C., Jennings, S. G., O’Dowd, C. D., Marinoni, A., Horn, H.-G., Keck, L., Jiang, J., Scheckman, J., McMurry, P. H., Deng, Z., Zhao, C. S., Moerman, M., Henzing, B., de Leeuw, G., Löschau, G., and
Bastian, S.: Mobility particle size spectrometers: harmonization of technical standards and data structure to facilitate high quality long-term observations of atmospheric particle number size distributions, Atmos. Meas. Tech., 5, 657-685, doi:10.5194/amt5-657-2012, 2012. 